Prepared in cooperation with the Albuquerque Bernalillo County Water Utility Authority

Selected Investigations and Statistical Summary of Surface-Water Quality in the Rio Grande and the Rio Chama, North-Central New Mexico, During Water Years 1985-2007

Data Series 629 



\section{Selected Investigations and Statistical Summary of Surface-Water Quality in the Rio Grande and the Rio Chama, North-Central New Mexico, During Water Years 1985-2007}

By Sarah E. Falk, Scott K. Anderholm, and Nicholas B. Engdahl

Prepared in cooperation with the

Albuquerque Bernalillo County Water Utility Authority

Data Series 629 


\section{U.S. Department of the Interior \\ KEN SALAZAR, Secretary \\ U.S. Geological Survey \\ Marcia K. McNutt, Director}

U.S. Geological Survey, Reston, Virginia: 2011

This and other USGS information products are available at http://store.usgs.gov/

U.S. Geological Survey

Box 25286, Denver Federal Center

Denver, C0 80225

To learn about the USGS and its information products visit http://www.usgs.gov/ 1-888-ASK-USGS

Any use of trade, product, or firm names is for descriptive purposes only and does not imply endorsement by the U.S. Government.

Although this report is in the public domain, permission must be secured from the individual copyright owners to reproduce any copyrighted materials contained within this report.

Suggested citation:

Falk, S.E., Anderholm, S.K., and Engdahl, N.B., 2011, Selected investigations and statistical summary of surface-water quality in the Rio Grande and the Rio Chama, north-central New Mexico, during water years 1985-2007: U.S. Geological Survey Data Series 629, 36 p. + appendixes. 


\section{Acknowledgments}

The authors thank the Albuquerque Bernalillo County Water Utility Authority (ABCWUA) for supporting this investigation. In particular, the authors wish to acknowledge John Stomp of the ABCWUA for his foresight, guidance, and support of this investigation and other studies to help better understand the water resources of New Mexico.

Various Federal and State agencies are acknowledged for providing information and data for this report. Specifically, we thank Los Alamos National Laboratory, the New Mexico Environment Department, the U.S. Fish and Wildlife Service, and the U.S. Environmental Protection Agency. Many questions about various aspects of the data used in this report came up during analysis. The following individuals were especially helpful in clarifying information used in this report: Bill Hardesty and Jean Dewart of Los Alamos National Laboratory, Scott Hopkins of the New Mexico Environment Department, and Cynthia Abeyta and Joel Lusk of the U.S. Fish and Wildlife Service.

\section{Contents}

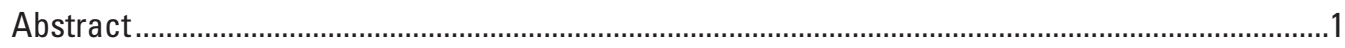

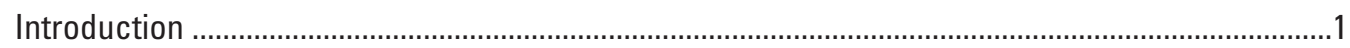

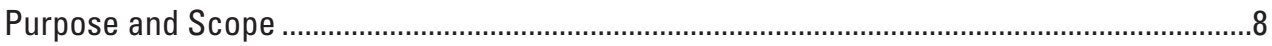

Selected Investigations of Surface-Water Quality ............................................................................

2007 Investigations of Surface-Water Quality ........................................................................

Statistical Summary of Selected Surface-Water-Quality Data.......................................................10

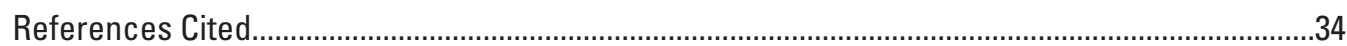

\section{Figures}

1. U.S. Geological Survey and Los Alamos National Laboratory water-quality stations in the study area near the Rio Grande and the Rio Chama in north-central New Mexico....

2. New Mexico Environment Department and U.S. Fish and Wildlife Service water-quality stations in the study area near the Rio Grande and the Rio Chama in north-central New Mexico.

\section{Tables}

1. U.S. Geological Survey water-quality station information near the Rio Grande and the Rio Chama in north-central New Mexico.

2. Los Alamos National Laboratory water-quality station information near the Rio Grande and the Rio Chama in north-central New Mexico.

3. New Mexico Environment Department water-quality station information near the Rio Grande and the Rio Chama in north-central New Mexico. 
4. U.S. Fish and Wildlife Service water-quality station information near the Rio Grande and the Rio Chama in north-central New Mexico.

5. Primary drinking-water standards and maximum contaminant level goals promulgated by the U.S. Environmental Protection Agency.

6. Secondary drinking-water standards promulgated by the U.S. Environmental Protection Agency and noticeable effects above the standard.

7. Health-based screening levels developed by the U.S. Geological Survey, U.S. Environmental Protection Agency, Oregon Health and Science University, and the New Jersey Department of Environmental Protection.

8. Human-health screening levels for tapwater developed by the U.S. Environmental Protection Agency.

9. Derived concentration guide reference values for ingested water for operational U.S. Department of Energy facilities.

\section{Conversion Factors}

Inch/Pound to SI

\begin{tabular}{lcl}
\hline \multicolumn{1}{c}{ Multiply } & By & \multicolumn{1}{c}{ To obtain } \\
\hline mile $(\mathrm{mi})$ & Length & \\
\hline & 1.609 & kilometer $(\mathrm{km})$ \\
\hline 1 millirem $(\mathrm{mrem})$ & Radioactivity & \\
\hline picocurie per liter $(\mathrm{pCi} / \mathrm{L})$ & 10 & microsieverts $(\mu \mathrm{Sv})$ \\
\hline
\end{tabular}

Temperature in degrees Celsius $\left({ }^{\circ} \mathrm{C}\right)$ may be converted to degrees Fahrenheit $\left({ }^{\circ} \mathrm{F}\right)$ as follows:

${ }^{\circ} \mathrm{F}=\left(1.8 x^{\circ} \mathrm{C}\right)+32$

Temperature in degrees Fahrenheit $\left({ }^{\circ} \mathrm{F}\right)$ may be converted to degrees Celsius $\left({ }^{\circ} \mathrm{C}\right)$ as follows:

${ }^{\circ} \mathrm{C}=\left({ }^{\circ} \mathrm{F}-32\right) / 1.8$

Horizontal coordinate information is referenced to the North American Datum of 1983 (NAD 83).

Specific conductance is given in microsiemens per centimeter at 25 degrees Celsius $\left(\mu \mathrm{S} / \mathrm{cm}\right.$ at $\left.25^{\circ} \mathrm{C}\right)$.

1 picocurie per liter ( $\mathrm{pCi} / \mathrm{L}$ ) is equivalent to $10^{\wedge}-9$ microcuries per milliliter $(\mu \mathrm{Ci} / \mathrm{mL})$

Concentrations of chemical constituents in water are given either in milligrams per liter (mg/L), micrograms per liter $(\mu \mathrm{g} / \mathrm{L})$, nanograms per liter $(\mathrm{ng} / \mathrm{L})$, or picocuries per liter $(\mathrm{pCi} / \mathrm{L})$. 


\title{
Selected Investigations and Statistical Summary of Surface-Water Quality in the Rio Grande and the Rio Chama, North-Central New Mexico, During Water Years 1985-2007
}

\author{
By Sarah E. Falk, Scott K. Anderholm, and Nicholas B. Engdahl
}

\section{Abstract}

The Albuquerque Bernalillo County Water Utility Authority (ABCWUA) is supplementing the municipal water supply for Albuquerque, New Mexico, and the surrounding area with water diverted from the Rio Grande. The distribution of surface water for municipal supply has raised questions about the quality of water in the Rio Grande and the possibility of contaminants in the water. The U.S. Geological Survey, in cooperation with $\mathrm{ABCWUA}$, has compiled existing waterquality data collected on the Rio Grande and its main tributary, the Rio Chama, by various Federal and State agencies to provide a comprehensive overview of water quality in the Rio Grande basin upstream from Albuquerque. This report describes selected water-quality investigations conducted by various Federal and State agencies and 2007 USGS surfacewater-quality investigations and data-collection activities and presents a statistical summary of selected water-quality data collected on the Rio Grande and the Rio Chama in central and northern New Mexico.

\section{Introduction}

The Albuquerque Bernalillo County Water Utility Authority (ABCWUA) is supplementing the municipal water supply for Albuquerque, N. Mex., and the surrounding area with water diverted from the Rio Grande. Historically, groundwater has been pumped from the Santa Fe Group aquifer at a rate that has resulted in water-level declines in the aquifer near the metropolitan area (Bexfield and
Anderholm, 2002). The principal component of ABCWUA's strategy to obtain and develop sustainable sources of water is the San Juan-Chama Drinking Water Project, which includes a diversion dam, water treatment facilities, and a distribution system (City of Albuquerque, 1997). Water diverted from the Rio Grande will be treated by a "multistage purification process, which employs carbon filtration and ozone disinfection..." (Albuquerque Bernalillo County Water Utility Authority, 2011). The distribution of surface water for municipal supply has raised questions about the quality of water in the Rio Grande and the possibility of contaminants in the water.

The U.S. Geological Survey (USGS), in cooperation with ABCWUA, has compiled existing water-quality data from water year (WY) 1985 through WY 2005 (October 1, 1985, to September 30, 2005) collected on the Rio Grande and its main tributary, the Rio Chama, by various Federal and State agencies to provide a comprehensive overview of water quality in the Rio Grande basin upstream of Albuquerque. The study area, comprising the Rio Grande and the Rio Chama in central and northern New Mexico (figs. 1 and 2), includes water-quality stations from the USGS (fig. 1 and table 1), the Los Alamos National Laboratory (LANL; fig. 1 and table 2), the New Mexico Environment Department (NMED; fig. 2 and table 3), and the U.S. Fish and Wildlife Service (USFWS; fig. 2 and table 4). Previous investigations have analyzed water samples for a wide range of constituents including physical properties, major ions, trace elements, nutrients, various radionuclides, and various organic compounds including explosives, herbicides, pesticides, volatile organic compounds, and pharmaceuticals. 


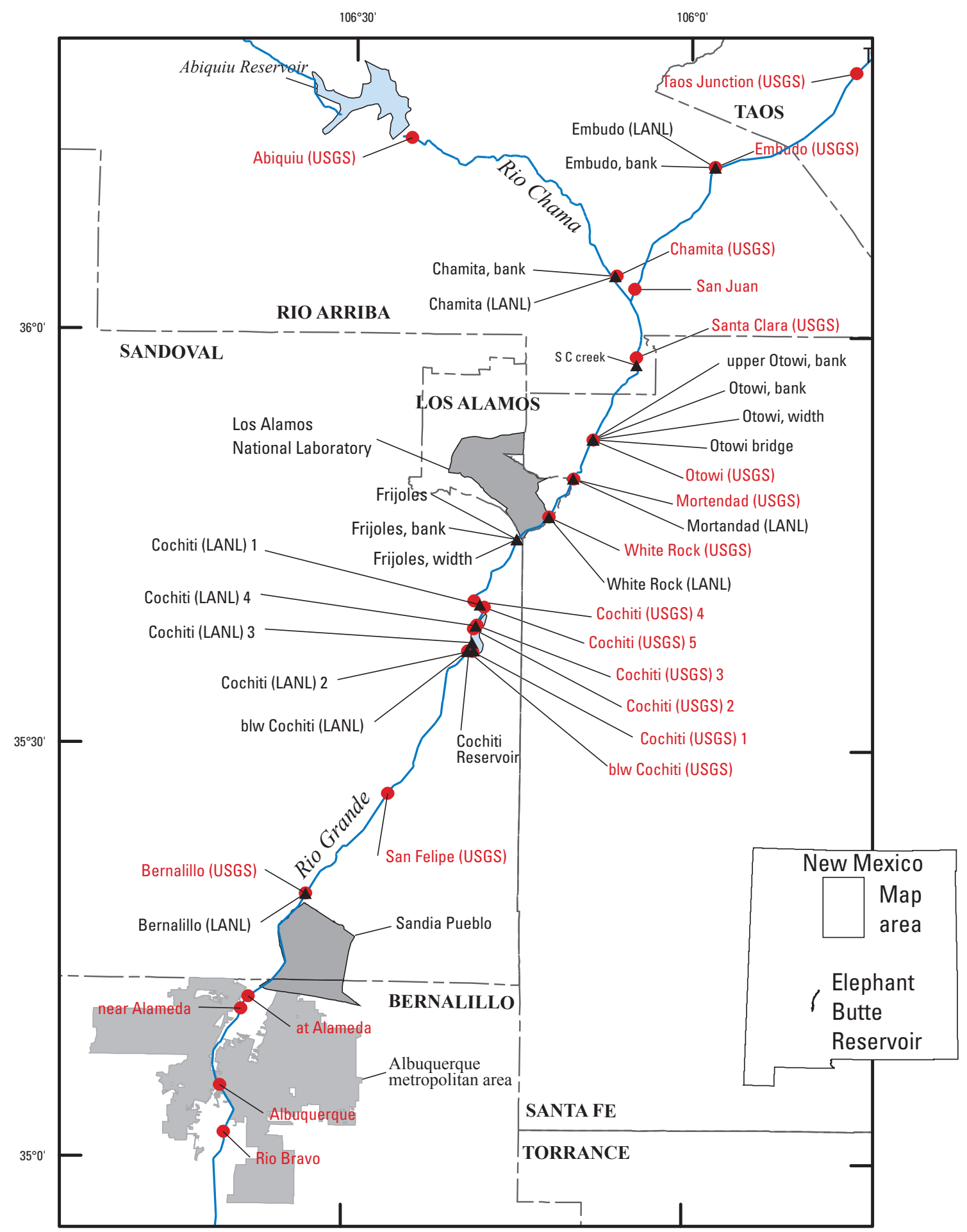

Base from U.S. Geological Survey digital data, 1999, 1:100,000

County line derived from the U.S. Department of Commerce, Bureau of the Census, 1994, TIGER/Line files, digital data, 1:100,000 Universal Transverse Mercator Zone 13N projection and North American Datum of 1983

\section{EXPLANATION}

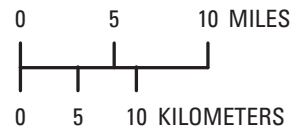

- U.S. Geological Survey (USGS) water-quality station name (table 1)

- Los Alamos National Laboratory (LANL) water-quality station name (table 2)

Figure 1. U.S. Geological Survey and Los Alamos National Laboratory water-quality stations in the study area near the Rio Grande and the Rio Chama in north-central New Mexico. 
Table 1. U.S. Geological Survey water-quality station information near the Rio Grande and the Rio Chama in north-central New Mexico.

[USGS, U.S. Geological Survey; NAD 83, North American Datum of 1983; nr, near; blw, below; Hwy, Highway]

\begin{tabular}{|c|c|c|c|c|}
\hline $\begin{array}{l}\text { USGS station } \\
\text { number }\end{array}$ & USGS station name & $\begin{array}{l}\text { Report station name } \\
\text { (fig. 1) }\end{array}$ & $\begin{array}{l}\text { Latitude } \\
\text { (NAD 83) }\end{array}$ & $\begin{array}{l}\text { Longitude } \\
\text { (NAD 83) }\end{array}$ \\
\hline 08317300 & Cochiti Lake near Cochiti Pueblo, N. Mex. & Cochiti (USGS) 1 & $35^{\circ} 40^{\prime} 41^{\prime \prime}$ & $106^{\circ} 18^{\prime} 55^{\prime \prime}$ \\
\hline 08313408 & Cochiti Lake (site D) nr Cochiti Pueblo, N. Mex. & Cochiti (USGS) 4 & $35^{\circ} 38^{\prime} 57^{\prime \prime}$ & $106^{\circ} 18^{\prime} 41^{\prime \prime}$ \\
\hline 08317298 & Cochiti Lake (site B) nr Cochiti Pueblo, N. Mex. & Cochiti (USGS) 2 & $35^{\circ} 37^{\prime} 10^{\prime \prime}$ & $106^{\circ} 19^{\prime} 00^{\prime \prime}$ \\
\hline 08287000 & Rio Chama below Abiquiu Dam, N. Mex. & Abiquiu (USGS) & $36^{\circ} 14^{\prime} 13^{\prime \prime}$ & $106^{\circ} 24^{\prime} 59^{\prime \prime}$ \\
\hline 08290000 & Rio Chama nr Chamita, N. Mex. & Chamita (USGS) & $36^{\circ} 04^{\prime} 22^{\prime \prime}$ & $106^{\circ} 06^{\prime} 34^{\prime \prime}$ \\
\hline 08281100 & Rio Grande above San Juan Pueblo, N. Mex. & San Juan & $36^{\circ} 03^{\prime} 25^{\prime \prime}$ & $106^{\circ} 04^{\prime} 56^{\prime \prime}$ \\
\hline 08291600 & Rio Grande at Santa Clara, N. Mex. & Santa Clara (USGS) & $35^{\circ} 58^{\prime} 28^{\prime \prime}$ & $106^{\circ} 04^{\prime} 43^{\prime \prime}$ \\
\hline 08313000 & Rio Grande at Otowi Bridge, N. Mex. & Otowi (USGS) & $35^{\circ} 52^{\prime} 28^{\prime \prime}$ & $106^{\circ} 08^{\prime} 30^{\prime \prime}$ \\
\hline 354936106101110 & Rio Grande at mouth of Mortendad Canyon, N. Mex. & Mortendad (USGS) & $35^{\circ} 49^{\prime} 36^{\prime \prime}$ & $106^{\circ} 10^{\prime} 13^{\prime \prime}$ \\
\hline 08313268 & Rio Grande near White Rock, N. Mex. & White Rock (USGS) & $35^{\circ} 46^{\prime} 51^{\prime \prime}$ & $106^{\circ} 12^{\prime} 23^{\prime \prime}$ \\
\hline 08317400 & Rio Grande below Cochiti Dam, N. Mex. & blw Cochiti (USGS) & $35^{\circ} 37^{\prime} 04^{\prime \prime}$ & $106^{\circ} 19^{\prime} 25^{\prime \prime}$ \\
\hline 08330000 & Rio Grande at Albuquerque, N. Mex. & Albuquerque & $35^{\circ} 05^{\prime} 21^{\prime \prime}$ & $106^{\circ} 40^{\prime} 49^{\prime \prime}$ \\
\hline 08330150 & Rio Grande at Rio Bravo Bridge near Albuquerque, N. Mex. & Rio Bravo & $35^{\circ} 01^{\prime} 59^{\prime \prime}$ & $106^{\circ} 40^{\prime} 25^{\prime \prime}$ \\
\hline
\end{tabular}


Table 2. Los Alamos National Laboratory water-quality station information near the Rio Grande and the Rio Chama in north-central New Mexico.

[Crk, creek; LANL, Los Alamos National Laboratory; NAD 83, North American Datum of 1983; wdth intgrt, width integrated]

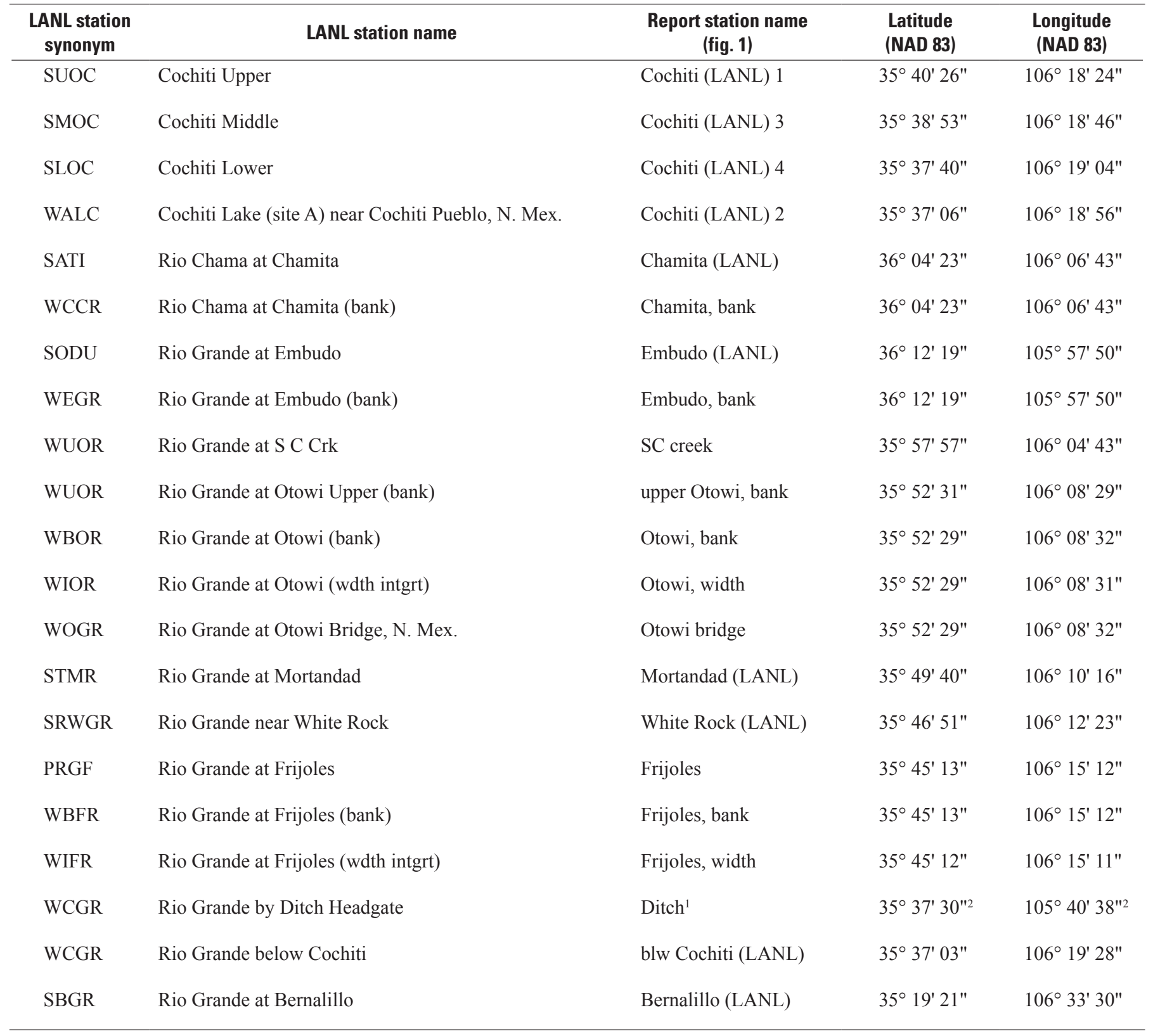

${ }^{1}$ Station not shown in figure 1.

${ }^{2}$ Location that was provided by LANL is not located on Rio Grande. 


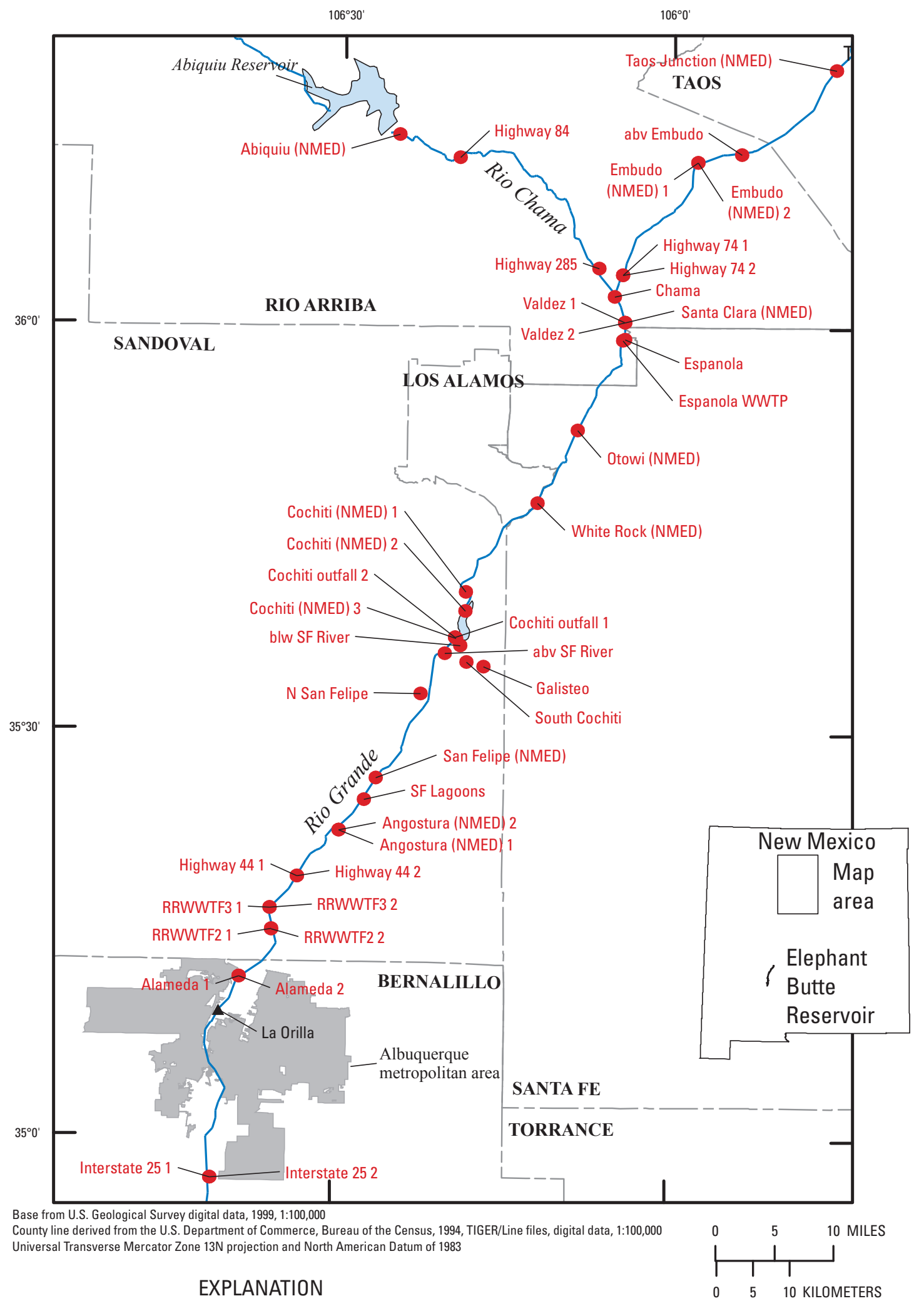

- U.S. Fish and Wildlife Service (USFWS) water-quality station name (table 4)

- New Mexico Environment Department (NMED) water-quality station name (table 3)

Figure 2. New Mexico Environment Department and U.S. Fish and Wildlife Service water-quality stations in the study area near the Rio Grande and the Rio Chama in north-central New Mexico. 
Table 3. New Mexico Environment Department water-quality station information near the Rio Grande and the Rio Chama in north-central New Mexico.

[NMED, New Mexico Environment Department; USEPA, U.S. Environmental Protection Agency; NAD 83, North American Datum of 1983; L, USEPA Legacy STORET database; M, USEPA Modernized STORET database; N, north; USGS, U.S. Geological Survey; blw, below; abv, above; @, at; Hwy, Highway; Cr., Creek; STP, Sewage Treatment Plant; yds, yards; WWTP, Waste Water Treatment Plant; SF, Santa Fe; WWTF, Waste Water Treatment Facility]

\begin{tabular}{|c|c|c|c|c|c|}
\hline $\begin{array}{l}\text { NMED station } \\
\text { identification }\end{array}$ & $\begin{array}{c}\text { USEPA } \\
\text { database }\end{array}$ & NMED station name & $\begin{array}{l}\text { Report station name } \\
\text { (fig. 2) }\end{array}$ & $\begin{array}{l}\text { Latitude } \\
\text { (NAD 83) }\end{array}$ & $\begin{array}{l}\text { Longitude } \\
\text { (NAD 83) }\end{array}$ \\
\hline $\mathrm{CBC}$ & $\mathrm{L}$ & Cochiti Lake near Bland Canyon & Cochiti (NMED) 1 & $35^{\circ} 40^{\prime} 27^{\prime \prime}$ & $106^{\circ} 18^{\prime} 30^{\prime \prime}$ \\
\hline COD & $\mathrm{L}$ & Cochiti Lake at the dam & Cochiti (NMED) 3 & $35^{\circ} 37^{\prime} 00^{\prime \prime}$ & $106^{\circ} 19^{\prime} 19^{\prime \prime}$ \\
\hline URG113.008020 & $\mathrm{L}$ & Rio Chama at US Highway 84 bridge near Abiquiu & Highway 84 & $36^{\circ} 12^{\prime} 33^{\prime \prime}$ & $106^{\circ} 19^{\prime} 28^{\prime \prime}$ \\
\hline URG113.004510 & $\mathrm{L}$ & Rio Chama at US Highway 285 at USGS Gage & Highway 285 & $36^{\circ} 04^{\prime} 26^{\prime \prime}$ & $106^{\circ} 06^{\prime} 42^{\prime \prime}$ \\
\hline TJB & $\mathrm{L}$ & Rio Grande blw Taos Junc bridge & Taos Junction (NMED) & $36^{\circ} 19^{\prime} 12^{\prime \prime}$ & $105^{\circ} 45^{\prime} 14^{\prime \prime}$ \\
\hline URG111.021035 & $\mathrm{L}$ & Rio Grande at the Embudo Gaging Station & Embudo (NMED) 2 & $36^{\circ} 12^{\prime} 20^{\prime \prime}$ & $105^{\circ} 57^{\prime} 49^{\prime \prime}$ \\
\hline 28RGRAND572.8 & M & Rio Grande at Highway 74 near San Juan Pueblo & Highway 741 & $36^{\circ} 03^{\prime} 58^{\prime \prime}$ & $106^{\circ} 04^{\prime} 34^{\prime \prime}$ \\
\hline URG111.021025 & $\mathrm{L}$ & Rio Grande at San Juan Pueblo at Hwy 74 Bridge & Highway 742 & $36^{\circ} 03^{\prime} 58^{\prime \prime}$ & $106^{\circ} 04^{\prime} 34^{\prime \prime}$ \\
\hline 28RGRAND569.4 & M & Rio Grande below Rio Chama & Chama & $36^{\circ} 02^{\prime} 23^{\prime \prime}$ & $106^{\circ} 05^{\prime} 17^{\prime \prime}$ \\
\hline 28RGRAND565.5 & M & Rio Grande above Espanola at Valdez Bridge & Valdez 1 & $36^{\circ} 00^{\prime} 27^{\prime \prime}$ & $106^{\circ} 04^{\prime} 20^{\prime \prime}$ \\
\hline URG111.004407 & $\mathrm{L}$ & Rio Grange abv Espanola at Valdez Bridge & Valdez 2 & $36^{\circ} 00^{\prime} 27^{\prime \prime}$ & $106^{\circ} 04^{\prime} 20^{\prime \prime}$ \\
\hline 28RGRAND533.6 & M & $\begin{array}{l}\text { Rio Grande at USGS Gage in White Rock Canyon } \\
\text { (near Water Can) }\end{array}$ & White Rock (NMED) & $35^{\circ} 47^{\prime} 05^{\prime \prime}$ & $106^{\circ} 12^{\prime} 05^{\prime \prime}$ \\
\hline MRG1 & $\mathrm{L}$ & Rio Grande at Cochiti Dam Outfall & Cochiti outfall 1 & $35^{\circ} 37^{\prime} 05^{\prime \prime}$ & $106^{\circ} 19^{\prime} 24^{\prime \prime}$ \\
\hline 30RGRAND507.2 & M & $\begin{array}{l}\text { Rio Grande at USGS Gage below Cochiti Reservoir } \\
\text { Outlet }\end{array}$ & Cochiti outfall 2 & $35^{\circ} 37^{\prime} 04^{\prime \prime}$ & $106^{\circ} 19^{\prime} 24^{\prime \prime}$ \\
\hline URG108.001060 & $\mathrm{L}$ & Rio Grande below Santa Fe River & blw SF River & $35^{\circ} 36^{\prime} 28^{\prime \prime}$ & $106^{\circ} 18^{\prime} 54^{\prime \prime}$ \\
\hline URG108.001080 & $\mathrm{L}$ & Rio Grande above Santa Fe River & abv SF River & $35^{\circ} 35^{\prime} 53^{\prime \prime}$ & $106^{\circ} 20^{\prime} 20^{\prime \prime}$ \\
\hline URG108.001020 & $\mathrm{L}$ & Rio Grande at Cochiti South Boundary & South Cochiti & $35^{\circ} 35^{\prime} 17^{\prime \prime}$ & $106^{\circ} 18^{\prime} 22^{\prime \prime}$ \\
\hline URG108.001005 & $\mathrm{L}$ & Rio Grande above Galisteo Creek & Galisteo & $35^{\circ} 34^{\prime} 56^{\prime \prime}$ & $106^{\circ} 16^{\prime} 49^{\prime \prime}$ \\
\hline URG108.000475 & $\mathrm{L}$ & Rio Grande at San Felipe N Boundary & N San Felipe & $35^{\circ} 32^{\prime} 53^{\prime \prime}$ & $106^{\circ} 22^{\prime} 27^{\prime \prime}$ \\
\hline
\end{tabular}


Table 3. New Mexico Environment Department water-quality station information near the Rio Grande and the Rio Chama in north-central New Mexico.-Continued

[NMED, New Mexico Environment Department; USEPA, U.S. Environmental Protection Agency; NAD 83, North American Datum of 1983; L, USEPA Legacy STORET database; M, USEPA Modernized STORET database; N, north; USGS, U.S. Geological Survey; blw, below; abv, above; @, at; Hwy, Highway; Cr., Creek; STP, Sewage Treatment Plant; yds, yards; WWTP, Waste Water Treatment Plant; SF, Santa Fe; WWTF, Waste Water Treatment Facility]

\begin{tabular}{|c|c|c|c|c|c|}
\hline $\begin{array}{l}\text { NMED station } \\
\text { identification }\end{array}$ & $\begin{array}{c}\text { USEPA } \\
\text { database }\end{array}$ & NMED station name & $\begin{array}{l}\text { Report station name } \\
\text { (fig. 2) }\end{array}$ & $\begin{array}{l}\text { Latitude } \\
\text { (NAD 83) }\end{array}$ & $\begin{array}{l}\text { Longitude } \\
\text { (NAD 83) }\end{array}$ \\
\hline URG108.000415 & $\mathrm{L}$ & Rio Grande at San Felipe Pueblo & San Felipe (NMED) & $35^{\circ} 26^{\prime} 39^{\prime \prime}$ & $106^{\circ} 26^{\prime} 23^{\prime \prime}$ \\
\hline 32RGRAND473.2 & M & Rio Grande Below Angostura Diversion Works & Angostura (NMED) 1 & $35^{\circ} 22^{\prime} 45^{\prime \prime}$ & $106^{\circ} 29^{\prime} 41^{\prime \prime}$ \\
\hline MRG105.005765 & $\mathrm{L}$ & Rio Grande at US Highway 44 Bridge & Highway 441 & $35^{\circ} 19^{\prime} 19^{\prime \prime}$ & $106^{\circ} 33^{\prime} 23^{\prime \prime}$ \\
\hline 32RGRAND464.2 & M & Rio Grande above Highway 44 Bridge & Highway 442 & $35^{\circ} 19^{\prime} 19^{\prime \prime}$ & $106^{\circ} 33^{\prime} 23^{\prime \prime}$ \\
\hline 32RGRAND458.0 & M & Rio Grande above Rio Rancho WWTF \#3 & RRWWTF3 1 & $35^{\circ} 16^{\prime} 58^{\prime \prime}$ & $106^{\circ} 35^{\prime} 49^{\prime \prime}$ \\
\hline MRG105.005749 & $\mathrm{L}$ & Rio Grande Upstream from RRU WWTF\#2 Discharge & RRWWTF2 2 & $35^{\circ} 15^{\prime} 23^{\prime \prime}$ & $106^{\circ} 35^{\prime} 37^{\prime \prime}$ \\
\hline MRG22B & $\mathrm{L}$ & Rio Grande at Alameda Bridge (Corrales Bridge) & Alameda 1 & $35^{\circ} 11^{\prime} 51^{\prime \prime}$ & $106^{\circ} 38^{\prime} 30^{\prime \prime}$ \\
\hline 32RGRAND445.4 & M & Rio Grande above Alameda Bridge & Alameda 2 & $35^{\circ} 11^{\prime} 51^{\prime \prime}$ & $106^{\circ} 38^{\prime} 30^{\prime \prime}$ \\
\hline MRG015 & $\mathrm{L}$ & Rio Grande at Interstate 25 Bridge & Interstate 251 & $34^{\circ} 56^{\prime} 58^{\prime \prime}$ & $106^{\circ} 40^{\prime} 49^{\prime \prime}$ \\
\hline 32RGRAND413.2 & M & Rio Grande above I-25 Bridge & Interstate 252 & $34^{\circ} 56^{\prime} 58^{\prime \prime}$ & $106^{\circ} 40^{\prime} 49^{\prime \prime}$ \\
\hline
\end{tabular}


Table 4. U.S. Fish and Wildlife Service water-quality station information near the Rio Grande and the Rio Chama in northcentral New Mexico.

[USFWS, U.S. Fish and Wildlife Service; NAD 83, North American Datum of 1983]

\begin{tabular}{lccc}
\hline & $\begin{array}{c}\text { Report } \\
\text { station name } \\
\text { (fig. 2) }\end{array}$ & $\begin{array}{c}\text { Latitude } \\
\text { (NAD 83) }\end{array}$ & $\begin{array}{c}\text { Longitude } \\
\text { (NAD 83) }\end{array}$ \\
\hline USFWS station name & La Orilla & $35^{\circ} 09^{\prime} 22^{\prime \prime}$ & $106^{\circ} 40^{\prime} 17^{\prime \prime}$ \\
\hline $\begin{array}{l}\text { Rio Grande at La Orilla, } \\
\text { N. Mex. }\end{array}$ & & & \\
\hline
\end{tabular}

\section{Purpose and Scope}

This report describes selected water-quality investigations conducted by various Federal and State agencies and 2007 USGS surface-water-quality investigations and datacollection activities and presents a statistical summary of selected water-quality data collected on the Rio Grande and its main tributary, the Rio Chama, in central and northern New Mexico. Data included in this report were collected by the USGS, the LANL, the NMED, and the USFWS. Results of selected water analyses are compared to water-quality standards. The water-quality data included in this report do not represent finished drinking-water samples, and any measured concentration that exceeds a Federal or State standard does not indicate a violation of drinking-water standards. The planned treatment process may reduce or eliminate many constituent concentrations detected in untreated surface-water samples, including bacteria and viruses.

\section{Selected Investigations of Surface-Water Quality}

In 1934, the U.S. Salinity Laboratory initiated a 30-year study to measure the quality of water in the Rio Grande, to determine the salt burden of the Rio Grande, and to calculate the salt-balance conditions along the Rio Grande (Wilcox, 1968). Data were collected during that study by the U.S. Bureau of Reclamation, the International Boundary and Water Commission, the USGS, and the U.S. Salinity Laboratory. A summary report was published in 1968 that included data and the calculated salt balances for the Rio Grande from Otowi Bridge, N. Mex., to Fort Quitman, Tex. (Wilcox, 1968). Wilcox (1968) found that the concentration of ions in water typically increased downstream and that salt balances in individual basins generally were positive (more salt entered the basin than was removed) during years of below normal streamflow and generally were negative during years of above normal streamflow.
Wilkins (1986) published a report summarizing the results of the Southwest Alluvial basins portion of the USGS Regional Aquifer-System Analysis program. Figures showing average surface-water quality for selected sites on the Rio Grande upstream of Fort Quitman were included and indicated that concentrations of analytes generally increased downstream from the headwaters and that upstream from Albuquerque calcium and bicarbonate were the principal dissolved constituents.

In 1992, the USGS National Water-Quality Assessment Program (NAWQA) initiated a series of studies to assess the quality of groundwater and surface water in the Rio Grande Valley from the headwaters to El Paso, Tex. Data on surfacewater quality were collected at selected sites monthly and during synoptic studies to determine composition of the water and to assess the correlation between land use and surfacewater quality. From 1992 to 1995, surface-water samples were collected at numerous locations in the Rio Grande basin and were analyzed for various constituents including trace elements, nutrients, and pesticides.

Anderholm and others (1995) summarized available nutrient, suspended sediment, and pesticide data for the Rio Grande from the headwaters to El Paso. They found that nutrient concentrations generally were small upstream of Albuquerque. Surface-water samples were analyzed for a range of chlorinated insecticides and polychlorinated biphenyls, organophosphorus insecticides, and herbicides. Of the 5,192 analyses for individual compounds, 98 percent of the results were censored, and DDT (dichlorodiphenyltrichloroethane) and its degradation products (diazinon and 2,4-D) were the most commonly detected pesticides (Anderholm and others, 1995). Carter (1997) presented the results of bed sediment and fish tissue sampling and reported that DDT and DDT-degradation compounds were common in fish tissue but seldom detected in bed sediment. Miller and others (1997) presented data collected during a synoptic study of trace element concentrations in surface water upstream of Albuquerque, and Taylor and others (2001) discussed the results of the sampling. Taylor and others (2001) indicated that runoff from the Creede mining district near the headwaters of the Rio Grande contributed to the concentration of dissolved trace elements in the Rio Grande for a distance of about 100 miles downstream. The Red River mining district did not appear to contribute to the concentration of dissolved trace elements in the Rio Grande. Taylor and others (2001) reported that, with the exception of cadmium at one site near the Creede mining district, no concentration of trace elements exceeded USEPA primary drinking-water standards. Healy (1997) discussed the results of monthly surface-water sampling along the Rio Grande. Healy (1997) found that dissolved-ion concentrations generally increased downstream as the result of natural sources, irrigation-return flow, wastewater treatment plant inflow, and urban runoff. Healy (1997) also noted that five pesticides including diazinon, s-Ethyl dipropylthiocarbamate (EPTC), malathion, simazine, and tebuthiuron were detected 
at amounts greater than the method detection limit in samples collected at sample site Rio Grande at Otowi Bridge. Moore and Anderholm (2002) evaluated spatial and temporal variations in dissolved solids, nitrate, total phosphorus, and suspended sediment concentrations and loads; they determined that ion concentration and load generally increase downstream from the New Mexico-Colorado State line as a result of increased streamflow.

The USGS, in cooperation with the City of Albuquerque, conducted a study to measure concentrations of dissolved trace elements and calculate instantaneous loads of selected trace elements and other constituents in the Rio Grande (Kelly and Taylor, 1996). Surface-water samples were collected at seven sites on the Rio Grande from near Bernalillo, N. Mex., to upstream of Isleta Diversion Dam, N. Mex., from May to October 1994 (Kelly and Taylor, 1996). Kelly and Taylor (1996) concluded that dissolved concentrations of trace elements generally increased downstream of the Albuquerque Wastewater Treatment Facility, that concentrations of dissolved trace elements did not significantly increase downstream of the effluent channel during periods of high flow, and that concentrations of dissolved trace elements increased downstream from Bernalillo to Isleta Diversion Dam during periods of low flow. Kelly and Taylor (1996) also noted that all measured concentrations were less than New Mexico water-quality standards for water designated as domestic or livestock supply.

Eight sites on the Rio Grande from the Pueblo of San Felipe, N. Mex., to Los Lunas, N. Mex., were sampled quarterly from October 1994 to August 1996 as part of a larger study conducted by the USGS. The purpose of that study was to determine ambient concentrations and loads of trace elements in the Rio Grande and to determine the mean concentrations of inorganic and organic forms of arsenic in the edible parts of fish tissue (Wilcox, 1997). Wilcox (1997) determined that dissolved-solids concentrations and dissolvedarsenic concentrations increased downstream from the Rio Grande at San Felipe Pueblo to Los Lunas, that nearly all arsenic measured in the Rio Grande was in the dissolved phase, and that major ion and trace element concentrations generally were greatest in outfall from wastewater treatment facilities.

The USGS, in cooperation with other Federal, State, and local agencies, conducted a 6-year (1995-2001) study of the Middle Rio Grande basin with the objective of improving the understanding of the hydrology, geology, and land-surface characteristics of the basin (Bartolino and Cole, 2002).

Surface-water samples were collected from the Rio Grande, tributaries to the Rio Grande, irrigation canals, and surface drains (Plummer and others, 2004). Plummer and others (2004) concluded that isotopic variations in the Rio Grande are caused by seasonal variation in source waters. Measured tritium concentrations in the Rio Grande at Alameda, N. Mex., ranged from 7.2 to 11 tritium units (TU) and showed a distinct increase in concentration during summer 1997 (Plummer and others, 2004). Major and minor trace element data are further detailed in Plummer and others (2004).

The State of New Mexico initiated a survey to measure concentrations of pharmaceutical residuals in water from various locations across the State (McQuillan and others, 2002). Water samples were collected from 15 sewage effluent locations, 23 surface-water locations, 9 groundwater locations, and 2 public drinking-water supply systems; these samples were analyzed for various analgesics, anticonvulsants, antidepressants, anti-inflammatory compounds, hormones, antibiotics, caffeine, and tamoxifen (McQuillan and others, 2002). All sewage effluent samples in the Rio Grande watershed above Albuquerque contained at least one drug residue; an antidepressant was detected in a sample collected at Buckman Crossing, and a hormone and esterone were detected downstream of the Albuquerque wastewater treatment facility (McQuillan and others, 2002).

Results presented in a USFWS draft report show a small number of volatile organic compounds, pesticides, herbicides, explosives, and pharmaceuticals detected in water samples at levels greater than laboratory reporting limits or method detection (Abeyta and Lusk, 2004). Physical property measurements across channel transects indicated increased variability near the riverbanks, and physical property measurements from continuous monitoring probes indicated diurnal temperature variation and wide variation in specific conductance, dissolved oxygen, and turbidity (Abeyta and Lusk, 2004).

In 2000 and 2001, after the Cerro Grande fire near Los Alamos, N. Mex., the USGS collected surface-water samples from the Rio Grande and Cochiti Reservoir to monitor storm runoff events in watersheds affected by the fire. Concentrations of radionuclides including cesium-137, strontium-90, plutonium-238, and plutonium-239/240 measured in the Rio Grande after major storm events in 2001 and 2003 were greater than concentrations measured in base flow (Gallaher and Koch, 2004, p. 156-157). Sediment samples collected from Cochiti Reservoir after the fire indicated increased concentrations of cesium-137, plutonium-238, and plutonium-239 (Gallaher and Koch, 2004). Additional results are summarized in Gallaher and Koch (2004).

Langman and Anderholm (2004) described the effects of reservoir installation and operation and the introduction of water from the San Juan-Chama Project (SJCP) on water quality and suspended-sediment concentrations in the Rio Grande and Rio Chama. The authors concluded that extreme streamflow decreased and that median streamflow increased after installation of dams and the addition of water from the SJCP. Langman and Anderholm (2004) also concluded that reservoirs attenuated the water-quality dilution from snowmelt runoff and that the influence of the SJCP and reservoirs diminished downstream.

Passell and others $(2004,2005)$ used water-quality data collected from 1975 to 1999 by the USGS on the Rio Grande to determine spatial and temporal trends for specific 
conductance; total dissolved solids; $\mathrm{pH}$; major ions including calcium, magnesium, sodium, potassium, chloride, fluoride, sulfate, bicarbonate, and silicate; and nutrients including total organic carbon, ammonium plus organic nitrogen, ammonium, nitrate plus nitrite, phosphorus, and orthophosphate. The water-quality data were collected as part of the USGS's National Stream Quality Accounting Network (NASQAN) and NAWQA. Temporal trends generally indicated improved quality of the water over time likely because of improved water treatment (Passell and others, 2004, 2005). Seasonal variation in water quality was correlated with seasonal variation in discharge, suggesting that improved water quality was partially caused by dilution from increased discharge (Passell and others, 2004, 2005). Spatial trends indicated that $\mathrm{pH}$, major ion, and nutrient concentrations increased downstream of Albuquerque and likely were affected by effluent discharge, by river geomorphology, and possibly by discharge of saline groundwater to the river (Passell and others, 2004, 2005).

In 2002 and 2003, the LANL conducted a study of polychlorinated biphenyl (PCB) concentrations in the Rio Grande upstream and downstream of the laboratory boundary (Gonzalez and Montoya, 2005). Samples were collected by using semipermeable membrane devices. PCB concentrations in the Rio Grande upstream of Cochiti Reservoir were less than concentrations downstream of the reservoir, and PCB concentrations were similar upstream and downstream of the laboratory boundary (Gonzalez and Montoya, 2005). The report concluded that the LANL did not contribute to PCB concentrations in the Rio Grande during the sampling periods.

Langman and Nolan (2005) characterized streamflow and water-quality trends of the Rio Grande and Rio Chama during WYs 1985 to 2002 and concluded that streamflow in the Rio Grande and Rio Chama follows seasonal and climatic patterns and that water quality generally decreases downstream as indicated by an increase in specific conductance downstream. Langman and Nolan (2005) determined that water quality in the Rio Grande and the Rio Chama was affected by reservoir management and groundwater inflows. The authors noted that median concentrations of trace elements and maximum concentrations of radionuclides and anthropogenic compounds did not exceed drinking-water standards (Langman and Nolan, 2005).

\section{Investigations of Surface-Water Quality}

The USGS, in cooperation with the ABCWUA, conducted several investigations on the Rio Grande and its tributaries in 2007. Water samples were collected at four sites on the Rio Grande, at one site on the Rio Chama, and at one site on the Jemez River to evaluate water-quality trends and determine concentrations of selected trace elements, organic compounds, and radionuclides. Samples were collected three times per year at the sites on the Rio Grande and Rio Chama and once per year on the Jemez River. Continuous specific conductance and water temperature were measured at three sites on the Rio Grande and at three sites on the Rio Chama to determine short-term water-quality variations and the effects of snowmelt and summer thunderstorm runoff, operation of reservoirs, and the introduction of SJCP water on water quality. Water-quality profiles were measured in Abiquiu and Cochiti Reservoirs to determine variations in water quality throughout those reservoirs. Data were evaluated to determine travel times in the Rio Grande downstream from Cochiti Reservoir.

\section{Statistical Summary of Selected Surface-Water-Quality Data}

The surface-water-quality data compiled for this report-collected by the USGS, the LANL, the NMED, and the USFWS - either were requested from the collecting agency or were obtained from an agency-supported database. Data that were not relevant to the study were removed; these data included those for sites outside the study area, sites that were not located on the main stem of the Rio Grande or the Rio Chama, samples that were collected before WY 1985 or after WY 2005, samples of media other than water, and quality-control samples such as blanks and replicates. Additional filtering criteria (detailed below) differed for each database. The authors assumed that each agency had reviewed their data prior to release; thus, the data compiled for this report were not reviewed for accuracy or correctness by the authors, and no attempt was made by the authors to evaluate quality-control samples.

The USGS has collected data as part of various Federal, State, and municipal projects with the focus of long-term monitoring of water quality. Data collection included many water-resources and water-quality studies conducted in cooperation with the City of Albuquerque and ABCWUA. Data were collected by following protocols outlined in the USGS National Field Manual for the Collection of WaterQuality Data (U.S. Geological Survey, variously dated), and water-quality constituents were analyzed by following the USGGS National Water Quality Laboratory, Denver, Colo., procedure outlined in the USGS Techniques of WaterResources Investigations Book 5: Laboratory Analysis (U.S. Geological Survey, variously dated) Details of individual studies are provided herein in the section "Selected Investigations of Surface-Water Quality."

Data collected by the USGS were retrieved from the National Water Information System (NWIS) on December 28, 2006, by hydrologic unit code (HUC) for the Rio Grande and the Rio Chama including HUCs 13020101, 13020102, and 13020201 through 13020211. Data that were removed included data that were not relevant to the study, results that were flagged as erroneous, and invalid data such as negative or zero values for analytes other than radionuclides (which can have negative values). Analytes determined by 
multiple methods (alkalinity or acid-neutralizing capacity and bicarbonate) were combined. All sites located on Cochiti Reservoir were combined.

The LANL has established an environmental surveillance program that includes annual sampling of water, air, and soil in areas possibly affected by laboratory activities. As part of the annual surveillance, the LANL collects surface-water samples on the Rio Grande and Rio Chama upstream of the laboratory boundary to characterize regional background conditions and downstream of the laboratory boundary to characterize the effect of laboratory activities on regional surface-water quality (Los Alamos National Laboratory, 2005). Water-quality samples (generally dip samples collected from the bank) are analyzed for a variety of constituents including general chemistry, major ions, trace elements, radionuclides, and a range of organic compounds including explosives (Los Alamos National Laboratory, 2005). Results from environmental monitoring at the LANL are published in an annual report that characterizes environmental management performance, summarizes environmental occurrences and responses, demonstrates compliance with applicable standards, and emphasizes significant programs and efforts (Los Alamos National Laboratory, 2005).

Water-quality data collected by the LANL were obtained from the Sandia Tritium workbook in the Oracle Discoverer interface of the LANL Water Quality Database, accessed at http://wqdbworld.lanl.gov/ on November 26, 2006. Data were retrieved for relevant surface-water sites (location type code "WCS" described as Watercourse) on the Rio Grande and Rio Chama and all sites on Cochiti Reservoir. Data that were removed included data that were not relevant to the study, results for which the method detection limit was greater than the reported result, results that did not indicate whether the sample was filtered or unfiltered, results that were flagged as erroneous, and invalid data such as negative or zero values for analytes other than radionuclides (which can have negative values). All sites located on Cochiti Reservoir were combined.

The NMED Surface Water Quality Bureau (SWQB), under the New Mexico Water Quality Act and the Federal Clean Water Act, established monitoring programs to assess the quality of surface water, to develop and update waterquality standards and discharge permits, to identify and prioritize water-quality problems, to develop total daily maximum load standards, and to assess existing water-quality controls and wetland restoration projects (New Mexico Environment Department, 2006). The monitoring program is rotated among water basins on an 8-year cycle that includes monthly sampling of rivers and streams from spring to fall and seasonal sampling of reservoirs and lakes (New Mexico Environment Department, 2006). Samples are analyzed for parameters that have applicable standards, and selected samples are analyzed for major ions, trace elements, and other toxic substances (New Mexico Environment Department, 2006). Samples are collected by using methods detailed in various SWQB publications (New Mexico Environment
Department, 2006). Results from the surveys are described in various reports that are available from the NMED.

Water-quality data collected by the NMED were obtained from the U.S. Environmental Protection Agency (USEPA) STORET Legacy (Legacy) and Modernized STORET (Modern) databases, accessed at http://www.epa.gov/storet/ dbtop.html on November 17, 2006. Data for Bernalillo, Los Alamos, Rio Arriba, Sandoval, Santa Fe, and Taos Counties were retrieved from the Legacy database, and data for the entire State of New Mexico was retrieved from the Modern database. Data from the Legacy and Modern databases were combined to generate a complete dataset from the NMED. Sample locations were combined by matching station names between the datasets, and analytes were combined by matching parameter names between the datasets. Some analyte matches required conversion of the reported analyte unit to ensure that units matched between databases, and if units were missing, they were determined either from the listed USGS parameter code or from the listed method code. Sample fractions were separated into dissolved and total, which included total, whole, total recoverable, and whole recoverable. Data not relevant to the study were removed. All sites located on Cochiti Reservoir were combined.

In 2002, the USFWS began an assessment of the effect of water-quality conditions on the health of the silvery minnow (Hybognathus amarus) in the Middle Rio Grande (Abeyta and Lusk, 2004). Samples were collected from 14 sites along the Rio Grande between the southern border of Sandia Pueblo and the northern edge of Elephant Butte Reservoir. Field parameters, including water temperature, $\mathrm{pH}$, specific conductance, dissolved oxygen, and turbidity, were measured, and composite samples for laboratory analysis were collected in low-velocity, shallow areas (C. Abeyta, USFWS, written commun., 2007). Filtered samples were analyzed for total dissolved solids, common anions, major ions, trace elements, and perchlorate, and unfiltered samples were analyzed for alkalinity, total suspended solids, hardness, total cyanide, nutrients, biological oxygen demand, chemical oxygen demand, and organic compounds including volatile organic compounds, pesticides, herbicides, explosives, and pharmaceuticals.

Data collected by the USFWS were provided by the agency in a spreadsheet of water-quality data associated with a draft report (Abeyta and Lusk, 2004). Data not relevant to the study were removed.

Nonparametric statistical methods, which are dependent on the relative position of numerically ranked data (Helsel, 2005), were applied to calculate summary statistics. Summary statistics - including median and maximum concentrations, the number of samples analyzed, and the percentage of values that were censored-were calculated for all constituents for which two or more values were available.

Most of the available data were values that are less than a threshold value and are imprecisely known and denoted as censored (Helsel, 2005). The data obtained from the USGS, the LANL, and the NMED denoted censored data with a 
qualifier code that indicated that the reported value was the threshold value. The data obtained from the USFWS denoted censored data by alteration of the reported value to indicate that the measured value was less than the associated reporting limit. All values that were less than or equal to the largest censored value for that constituent were raised to the largest censored value for statistical analysis.

Estimated values (measured values that are equal to or less than a threshold value) indicated that the analyte was present in the sample but that the actual concentration is imprecisely known. Estimated values in all databases were indicated by a qualifier code. The concentrations of estimated values were assumed to equal the estimated value for statistical analysis.

In general, analysis methods for radionuclides differ from methods for organic and inorganic constituents. Radionuclides are quantified by measuring the rate of radioactive decay, and the uncertainty of the measured value is a function of the length of time that is monitored for decay. The minimum detectable concentration (the minimum concentration required to give a specified probability that an analyte is present in a sample, U.S. Nuclear Regulatory Commission, 2004, p. 20-6) determines the threshold for censoring a value. For this report, the databases did not provide the required information to define the threshold values and did not consistently designate censored data. Therefore, the reported values for radionuclides were assumed to be absolute concentrations unless the constituent was qualified as censored.

Results from analyses for radionuclides can be expressed in units of concentration $(\mu \mathrm{g} / \mathrm{L})$, activity $(\mathrm{pCi} / \mathrm{L}$ or $\mu \mathrm{Ci} / \mathrm{mL}$ ), or exposure (millirems). The conversion from units of concentration or activity to units of exposure is dependent on factors such as body mass, radionuclide species, and the amount of radionuclide consumed. In addition, given the same concentration or activity, different radionuclides would contribute different levels of exposure to the final exposure value. Because of the complexities, the equivalent exposure for the reported concentrations or activities of radionuclides are not presented in this report.

Results of selected water analyses are compared to (1) national drinking-water standards promulgated by the USEPA including primary standards (U.S. Environmental Protection Agency, 2007a) and secondary standards (U.S. Environmental Protection Agency, 2007b); (2) health-based screening levels (HBSL) developed by the USGS, USEPA, Oregon Health and Science University (OSHU), and the New Jersey Department of Environmental Protection (NJDEP; U.S. Geological Survey, 2007); (3) human-health screening levels for tapwater developed by the USEPA (U.S. Environmental Protection Agency, 2007c); and (4) derived concentration guide (DCG) reference values for operational U.S. Department of Energy (USDOE) facilities developed by the USDOE (U.S. Department of Energy, 2007). The comparison is useful to evaluate the suitability of surface water for municipal supply. Because the water-quality data for radionuclides were reported in units of concentration or activity, standards for radionuclides reported in units of exposure were not included in the comparison.

Primary drinking-water standards established by the USEPA (table 5) are either maximum contaminant levels or treatment techniques and are legally enforceable limits on concentrations of specific contaminants known to adversely affect human health (U.S. Environmental Protection Agency, 2011). Standards are the lowest concentration of a contaminant that can be achieved in drinking water with the best available and economically feasible technology and treatment techniques and are generally established with the objective of attaining the maximum contaminant level goal (the maximum concentration of a contaminant that does not cause adverse health effects, U.S. Environmental Protection Agency, 2011). Secondary drinking-water standards established by the USEPA (table 6) are non-enforceable guidelines for contaminants that may affect the cosmetic or aesthetic quality of the water (U.S. Environmental Protection Agency, 2011). The USGS, in cooperation with the USEPA, OHSU, and the NJDEP, developed HBSLs (table 7) to provide a context for interpretation of water-quality data for compounds with no existing drinking-water standards (Toccalino and others, 2003). Toccalino and others (2003) detailed the methods used to determine HBSLs, and Toccalino (2007) summarized revisions to the methodology used to determine HBSLs. The USEPA Region 6 developed screening levels (table 8) on the basis of fixed levels of risk associated with contaminant concentrations in soil, air, and water to aid in the process of closure and realignment of surplus military property (U.S. Environmental Protection Agency, 2007c, 2007d). The USDOE DCG reference values (table 9) are the concentrations of radionuclides at which continuous exposure for 1 year by a single mode (ingestion of water, submersion in air, or inhalation) would result in an effective dose equivalent of 100 millirems. The values were established to limit exposure of the public to radiation from USDOE facilities and activities to the lowest achievable level and to control radioactive contamination of the environment to the extent practical (U.S. Department of Energy, 2007). 
Table 5. Primary drinking-water standards and maximum contaminant level goals promulgated by the U.S. Environmental Protection Agency.

[Standards and goals from U.S. Environmental Protection Agency, 2007a. CASRN, Chemical Abstracts Service registry number; MCL, maximum contaminant level; TT, treatment technique; $\mathrm{mg} / \mathrm{L}$, milligrams per liter; $\mathrm{n} / \mathrm{a}$, not available; $\mathrm{N}$, nitrogen; $\mathrm{Cl}_{2}$, chlorine; $\mathrm{ClO}_{2}$, chlorine dioxide; $\mathrm{pCi} / \mathrm{L}$, picocuries per liter; mrem/year, millirems per year; $\mu \mathrm{g} / \mathrm{L}$, micrograms per liter; MRDL, maximum residual disinfectant level; MRDLG, maximum residual disinfectant level goal]

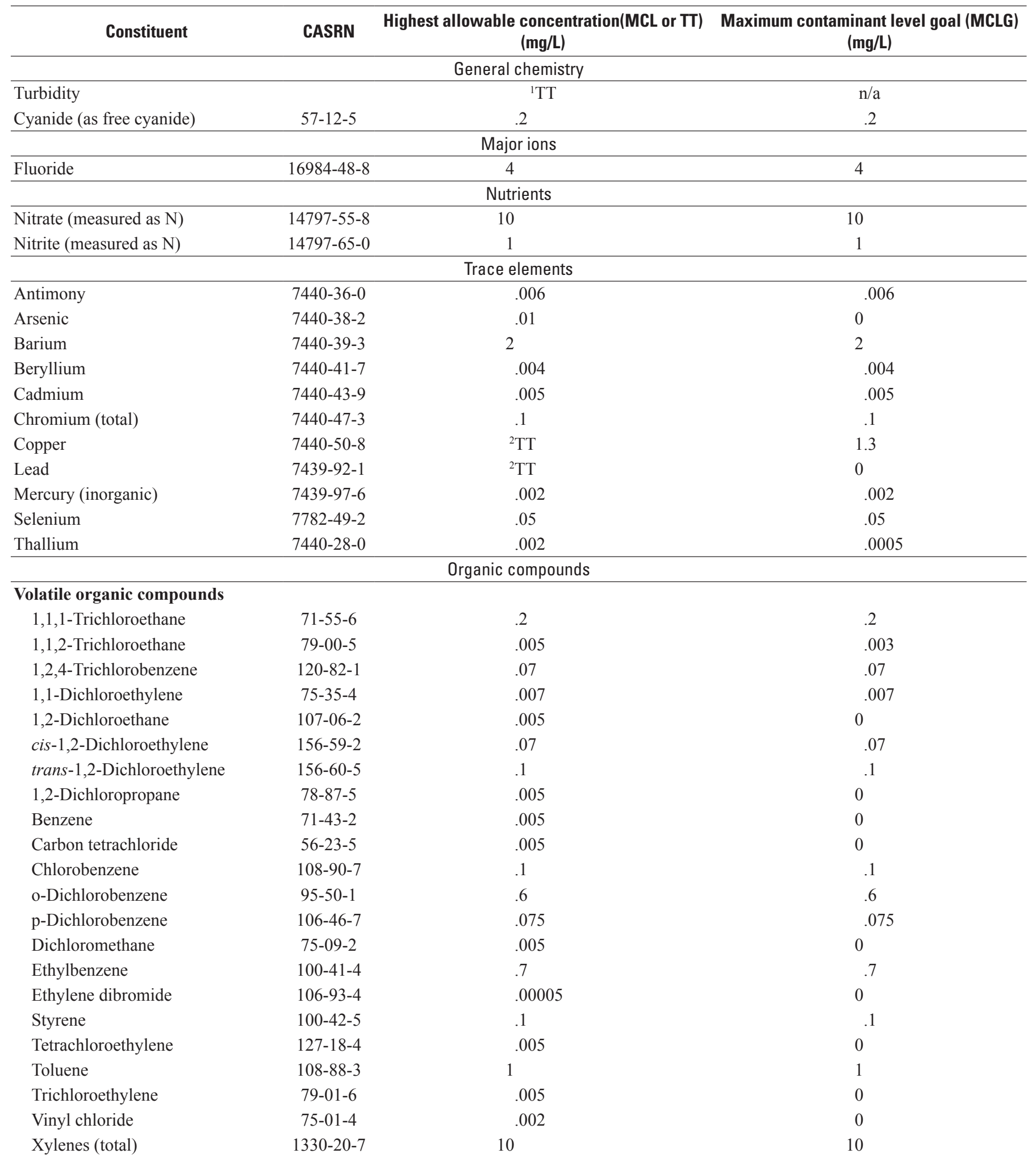


Table 5. Primary drinking-water standards and maximum contaminant level goals promulgated by the U.S. Environmental Protection Agency.-Continued

[Standards and goals from U.S. Environmental Protection Agency, 2007a. CASRN, Chemical Abstracts Service registry number; MCL, maximum contaminant level; TT, treatment technique; $\mathrm{mg} / \mathrm{L}$, milligrams per liter; $\mathrm{n} / \mathrm{a}$, not available; $\mathrm{N}$, nitrogen; $\mathrm{Cl}_{2}$, chlorine; $\mathrm{ClO}_{2}$, chlorine dioxide; $\mathrm{pCi} / \mathrm{L}$, picocuries per liter; mrem/year, millirems per year; $\mu \mathrm{g} / \mathrm{L}$, micrograms per liter; MRDL, maximum residual disinfectant level; MRDLG, maximum residual disinfectant level goal]

\begin{tabular}{|c|c|c|c|}
\hline Constituent & CASRN & $\begin{array}{l}\text { Highest allowable concentration (MCL or TT) } \\
\qquad(\mathrm{mg} / \mathrm{L})\end{array}$ & $\begin{array}{l}\text { Maximum contaminant level goal (MCLG) } \\
\text { (mg/L) }\end{array}$ \\
\hline \multicolumn{4}{|c|}{ Semivolatile organic compounds } \\
\hline Di(2-ethylhexyl) phthalate & $117-81-7$ & .006 & 0 \\
\hline Hexachlorobenzene & $118-74-1$ & .001 & 0 \\
\hline Hexachlorocyclopentadiene & $77-47-4$ & .05 & .05 \\
\hline \multicolumn{4}{|l|}{ Pesticides } \\
\hline 1,2-Dibromo-3-chloropropane & $96-12-8$ & .0002 & 0 \\
\hline $2,4,5-\mathrm{TP}$ & $93-72-1$ & .05 & .05 \\
\hline 2,4-D & $94-75-7$ & .07 & .07 \\
\hline Dalapon & 75-99-0 & .2 & .2 \\
\hline Dinoseb & $88-85-7$ & .007 & .007 \\
\hline Dioxin $(2,3,7,8$-TCDD) & $1746-01-6$ & .00000003 & 0 \\
\hline Diquat & $2764-72-9$ & .02 & .02 \\
\hline Endothall & $145-73-3$ & .1 & .1 \\
\hline Endrin & $72-20-8$ & .002 & .002 \\
\hline Glyphosate & $1071-83-6$ & .7 & .7 \\
\hline Heptachlor & $76-44-8$ & .0004 & 0 \\
\hline Heptachlor epoxide & $1024-57-3$ & .0002 & 0 \\
\hline \multicolumn{4}{|c|}{ Polyaromatic hydrocarbons } \\
\hline Benzo(a)pyrene (PAHs) & $50-32-8$ & .0002 & 0 \\
\hline \multicolumn{4}{|c|}{ Polychlorinated biphenyls } \\
\hline Polychlorinated biphenyls (PCBs) & $1336-36-3$ & .0005 & 0 \\
\hline \multicolumn{4}{|c|}{ Radionuclides } \\
\hline Alpha particles & & $15 \mathrm{pCi} / \mathrm{L}$ & 0 \\
\hline Beta particles and photon emitters & & $4 \mathrm{mrem} /$ year & 0 \\
\hline $\begin{array}{l}\text { Radium } 226 \text { and Radium } 228 \\
\quad \text { (combined) }\end{array}$ & & $5 \mathrm{pCi} / \mathrm{L}$ & 0 \\
\hline Tritium & & $20,000 \mathrm{pCi} / \mathrm{L}$ & \\
\hline Strontium-90 & & $8 \mathrm{pCi} / \mathrm{L}$ & \\
\hline Uranium & & $30 \mathrm{mg} / \mathrm{L}$ & 0 \\
\hline
\end{tabular}


Table 5. Primary drinking-water standards and maximum contaminant level goals promulgated by the U.S. Environmental Protection Agency.-Continued

[Standards and goals from U.S. Environmental Protection Agency, 2007a. CASRN, Chemical Abstracts Service registry number; MCL, maximum contaminant level; TT, treatment technique; $\mathrm{mg} / \mathrm{L}$, milligrams per liter; $\mathrm{n} / \mathrm{a}$, not available; $\mathrm{N}$, nitrogen; $\mathrm{Cl}_{2}$, chlorine; $\mathrm{ClO}_{2}$, chlorine dioxide; $\mathrm{pCi} / \mathrm{L}$, picocuries per liter; $\mathrm{mrem} /$ year, millirems per year; $\mu \mathrm{g} / \mathrm{L}$, micrograms per liter; MRDL, maximum residual disinfectant level; MRDLG, maximum residual disinfectant level goal]

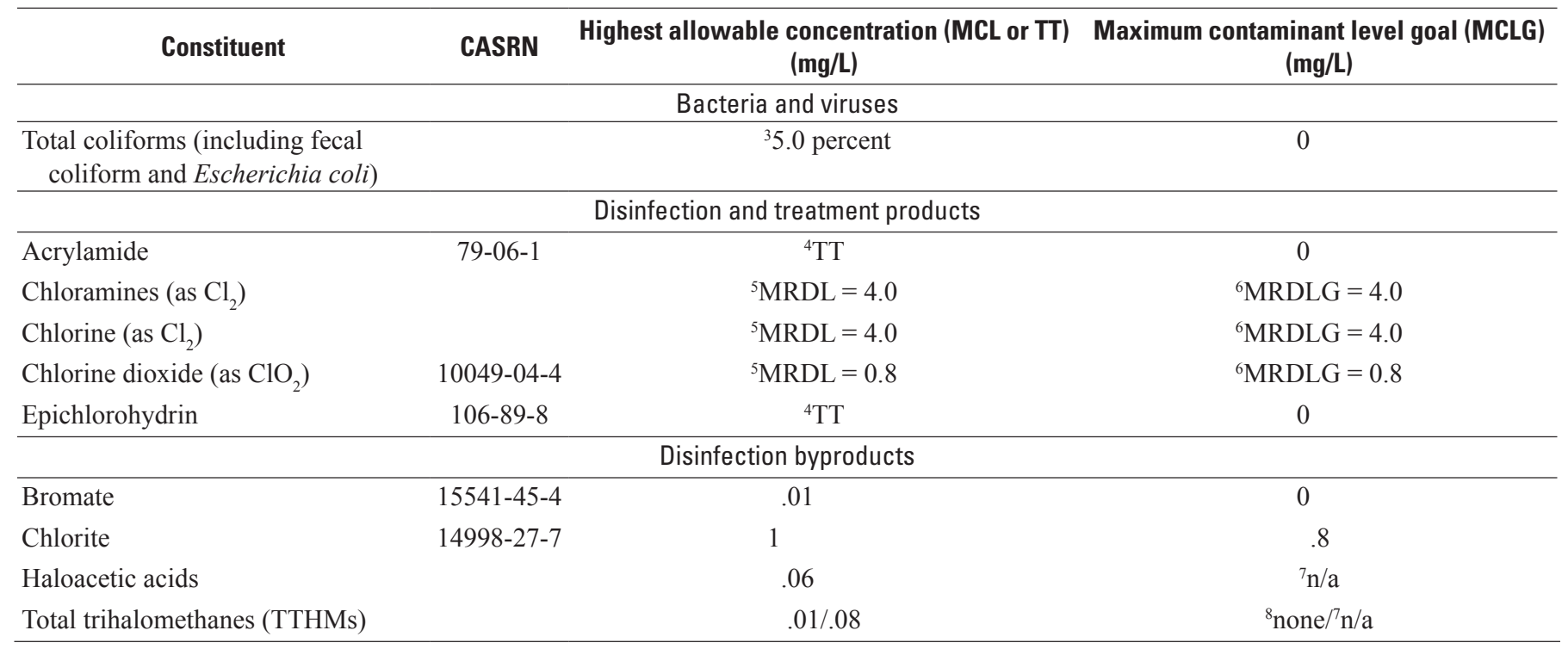

${ }^{1}$ Turbidity: At no time can turbidity (cloudiness of water) be greater than 5 nephelolometric turbidity units (NTU); systems that filter must ensure that the turbidity does not exceed 1 NTU ( 0.5 NTU for conventional or direct filtration) in at least 95 percent of the daily samples in any month. As of January 1,2002 , turbidity may never exceed 1 NTU and must not exceed 0.3 NTU in 95 percent of daily samples in any month.

${ }^{2}$ Lead and copper are regulated by a treatment technique that requires systems to control the corrosiveness of their water. If more than 10 percent of tapwater samples exceed the action level, water systems must take additional steps. For copper, the action level is $1.3 \mathrm{mg} / \mathrm{L}$, and for lead the action level is $0.015 \mathrm{mg} / \mathrm{L}$.

${ }^{3}$ More than 5.0 percent samples total coliform-positive in a month. (For water systems that collect fewer than 40 routine samples per month, no more than one sample can be total coliform-positive per month.) Every sample that has total coliform must be analyzed for either fecal coliforms or E. coli. In a system, if two consecutive samples are total coliform positive — one of which is also positive for E. coli fecal coliforms - then the system has an acute MCL violation.

${ }^{4}$ Each water system must certify, in writing, to the State (using third-party or manufacturer's certification) that, when acrylamide and epichlorohydrin are used in drinking-water systems, the combination (or product) of dose and monomer level does not exceed the levels specified, as follows: Acrylamide $=0.05$ percent dosed at $1 \mathrm{mg} / \mathrm{L}$ (or equivalent) and Epichlorohydrin $=0.01$ percent dosed at $20 \mathrm{mg} / \mathrm{L}$ (or equivalent).

${ }^{5}$ Maximum residual disinfectant level (MRDL) - The highest level of a disinfectant allowed in drinking water. There is convincing evidence that addition of a disinfectant is necessary for control of microbial contaminants.

${ }^{6}$ Maximum residual disinfectant level goal (MRDLG) - The level of a drinking-water disinfectant below which there is no known or expected risk to health. MRDLGs do not reflect the benefits of the use of disinfectants to control microbial contaminants.

${ }^{7}$ Although there is no collective MCLG for this contaminant group, there are individual MCLGs for some of the individual contaminants: Trihalomethanes: bromodichloromethane (zero); bromoform (zero); dibromochloromethane $(0.06 \mathrm{mg} / \mathrm{L}$ ). Chloroform is regulated with this group but has no MCLG. Haloacetic acids: dichloroacetic acid (zero); trichloroacetic acid $(0.3 \mathrm{mg} / \mathrm{L})$. Monochloroacetic acid, bromoacetic acid, and dibromoacetic acid are regulated with this group but have no MCLGs.

${ }^{8}$ MCLGs were not established before the 1986 Amendments to the Safe Drinking Water Act. Therefore, there is no MCLG for this contaminant. 
Table 6. Secondary drinking-water standards promulgated by the U.S. Environmental Protection Agency and noticeable effects above the standard.

[Standards and effects from U.S. Environmental Protection Agency, 2007b. mg/L, milligrams per liter]

\begin{tabular}{|c|c|c|}
\hline Constituent & $\begin{array}{l}\text { Secondary standard } \\
\text { (mg/L) }\end{array}$ & $\begin{array}{l}\text { Noticeable effects above the secondary } \\
\text { maximum contaminant level }\end{array}$ \\
\hline \multicolumn{3}{|c|}{ General chemistry } \\
\hline & & high pH: slippery feel; soda taste; deposits \\
\hline \multicolumn{3}{|c|}{ Major ions } \\
\hline Chloride & 250 & salty taste \\
\hline Fluoride & 2 & tooth discoloration \\
\hline Sulfate & 250 & salty taste \\
\hline Copper & 1 & metallic taste; blue-green staining \\
\hline Iron & .3 & rusty color; sediment; metallic taste; reddish or orange staining \\
\hline Manganese & .05 & black to brown color; black staining; bitter metallic taste \\
\hline Silver & .1 & skin discoloration; graying of the white part of the eye \\
\hline Zinc & 5 & metallic taste \\
\hline Odor & 3 threshold odor number & "rotten egg," musty, or chemical smell \\
\hline
\end{tabular}


Table 7. Health-based screening levels developed by the U.S. Geological Survey in cooperation with the U.S. Environmental Protection Agency, Oregon Health and Science University, and the New Jersey Department of Environmental Protection.

[Screening levels from U.S. Geological Survey, 2007. CASRN, Chemcial Abstracts Service registry number; USGS, U.S. Geological Survey; $\mu \mathrm{g} / \mathrm{L}$, micrograms per liter]

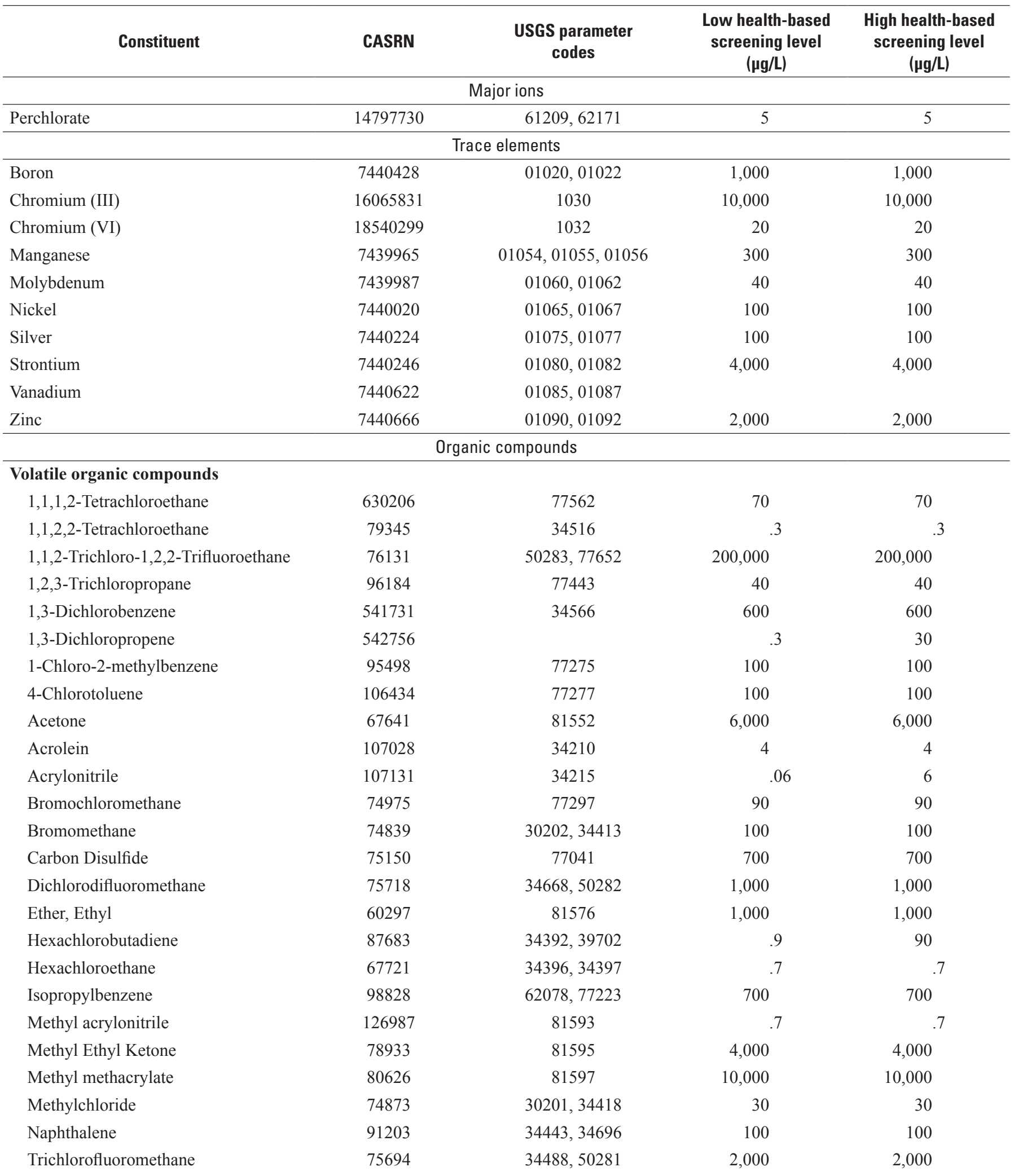


Table 7. Health-based screening levels developed by the U.S. Geological Survey in cooperation with the U.S. Environmental Protection Agency, Oregon Health and Science University, and the New Jersey Department of Environmental Protection.-Continued

[Screening levels from U.S. Geological Survey, 2007. CASRN, Chemcial Abstracts Service registry number; USGS, U.S. Geological Survey; $\mu \mathrm{g} / \mathrm{L}$, micrograms per liter]

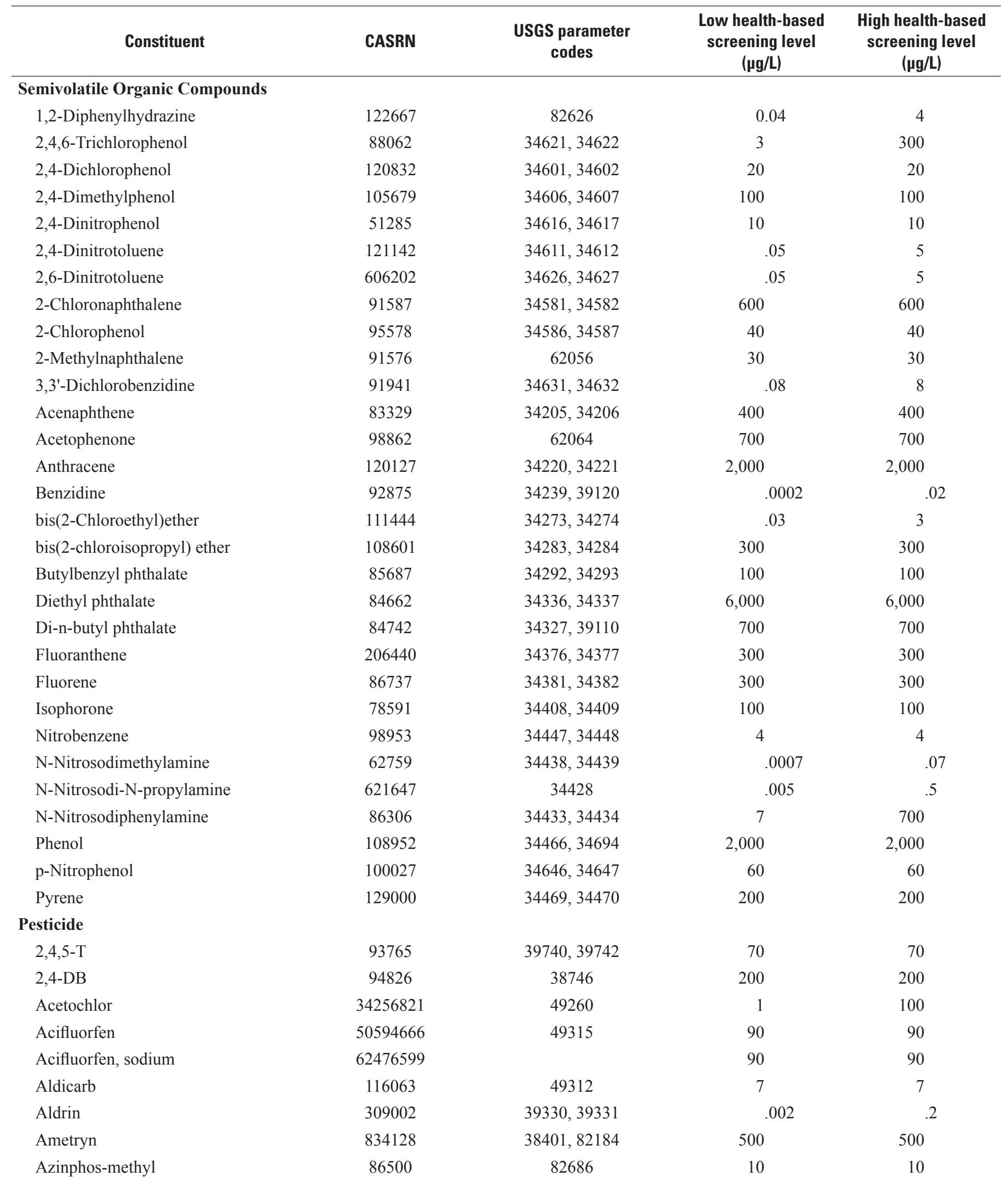


Table 7. Health-based screening levels developed by the U.S. Geological Survey in cooperation with the U.S. Environmental Protection Agency, Oregon Health and Science University, and the New Jersey Department of Environmental Protection.-Continued

[Screening levels from U.S. Geological Survey, 2007. CASRN, Chemcial Abstracts Service registry number; USGS, U.S. Geological Survey; $\mu \mathrm{g} / \mathrm{L}$, micrograms per liter]

\begin{tabular}{|c|c|c|c|c|}
\hline Constituent & CASRN & $\begin{array}{l}\text { USGS parameter } \\
\text { codes }\end{array}$ & $\begin{array}{c}\text { Low health-based } \\
\text { screening level } \\
(\mu \mathrm{g} / \mathrm{L})\end{array}$ & $\begin{array}{c}\text { High health-based } \\
\text { screening level } \\
(\mu \mathrm{g} / \mathrm{L})\end{array}$ \\
\hline Bendiocarb & 22781233 & 50299 & 9 & 9 \\
\hline Benfluralin & 1861401 & 82673 & 4 & 4 \\
\hline Benomyl & 17804352 & 50300 & 40 & 40 \\
\hline Bensulfuron-methyl & 83055996 & 61676,61693 & 1,000 & 1,000 \\
\hline Bentazon & 25057890 & 38711 & 200 & 200 \\
\hline beta-HCH & 319857 & 39338 & .04 & .04 \\
\hline Bifenthrin & 82657043 & 61580 & 10 & 10 \\
\hline Bromacil & 314409 & 04029,30234 & 70 & 70 \\
\hline Bromoxynil & 1689845 & 49311 & 10 & 10 \\
\hline Butylate & 2008415 & 04028,30236 & 400 & 400 \\
\hline Captan & 133062 & 61582 & 900 & 900 \\
\hline Carbaryl & 63252 & $39750,49310,82680$ & 40 & 4,000 \\
\hline Carboxin & 5234684 & 04027,30245 & 60 & 60 \\
\hline Chloramben & 133904 & 49307 & 100 & 100 \\
\hline Chlorimuron-ethyl & 90982324 & 50306,61677 & 600 & 600 \\
\hline Chlorothalonil & 1897456 & 49306,70314 & 5 & 500 \\
\hline Chlorpyrifos & 2921882 & 38932,38933 & 2 & 2 \\
\hline Chlorsulfuron & 64902723 & 61678 & 100 & 100 \\
\hline Cyanazine & 21725462 & $04041,50010,81757$ & 1 & 1 \\
\hline Cycloate & 1134232 & 04031,30254 & 40 & 40 \\
\hline Cyfluthrin & 68359375 & 61585 & 200 & 200 \\
\hline Cyhalothrin/Karate & 68085858 & & 40 & 40 \\
\hline Cypermethrin & 52315078 & 61586 & 40 & 40 \\
\hline Dacthal & 1861321 & 82682 & 70 & 70 \\
\hline Diazinon & 333415 & 39570,39572 & 1 & 1 \\
\hline Dicamba & 1918009 & 38442,82052 & 3,000 & 3,000 \\
\hline Dichlobenil & 1194656 & 49303 & 9 & 9 \\
\hline Dichlorvos & 62737 & 38775 & .4 & .4 \\
\hline Dicrotophos & 141662 & 38454 & .05 & .05 \\
\hline Dieldrin & 60571 & 39380,39381 & .002 & .2 \\
\hline Dimethoate & 60515 & 82662 & 2 & 2 \\
\hline Diphenamid & 957517 & 04033,30255 & 200 & 200 \\
\hline Disulfoton & 298044 & 39011,82677 & .9 & .9 \\
\hline Diuron & 330541 & 49300 & 2 & 200 \\
\hline Endosulfan & 115297 & 82354 & 40 & 40 \\
\hline EPTC & 759944 & 82668 & 200 & 200 \\
\hline Ethalfluralin & 55283686 & 82663 & 30 & 30 \\
\hline Ethion & 563122 & 39398,82346 & 4 & 4 \\
\hline Ethoprophos & 13194484 & 82672 & 1 & 100 \\
\hline Fenamiphos & 22224926 & 61591 & .7 & .7 \\
\hline Fenthion & 55389 & 38801 & .5 & .5 \\
\hline
\end{tabular}


Table 7. Health-based screening levels developed by the U.S. Geological Survey in cooperation with the U.S. Environmental Protection Agency, Oregon Health and Science University, and the New Jersey Department of Environmental Protection.-Continued

[Screening levels from U.S. Geological Survey, 2007. CASRN, Chemcial Abstracts Service registry number; USGS, U.S. Geological Survey; $\mu$ g/L, micrograms per liter]

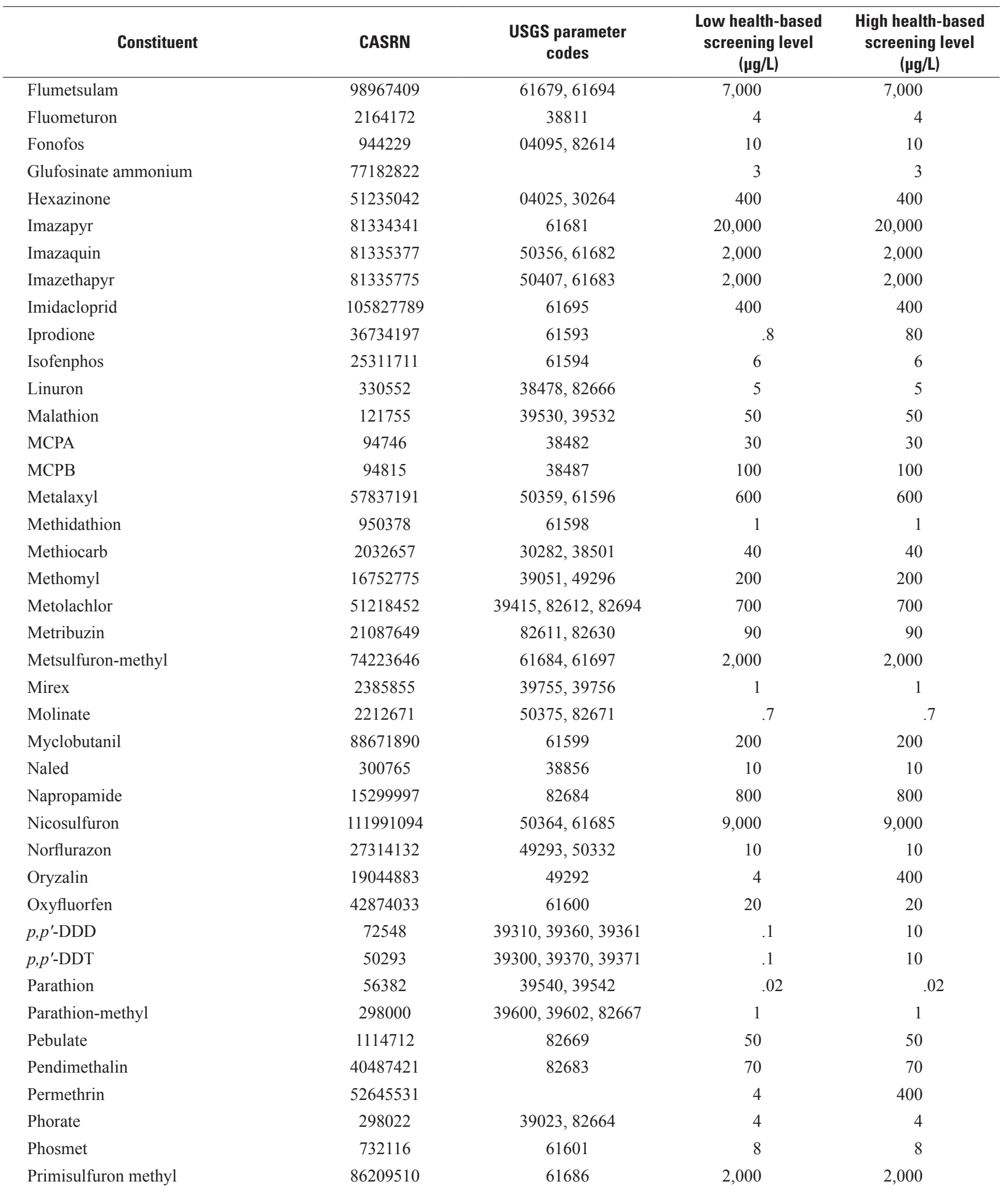


Table 7. Health-based screening levels developed by the U.S. Geological Survey in cooperation with the U.S. Environmental Protection Agency, Oregon Health and Science University, and the New Jersey Department of Environmental Protection.-Continued

[Screening levels from U.S. Geological Survey, 2007. CASRN, Chemcial Abstracts Service registry number; USGS, U.S. Geological Survey; $\mu \mathrm{g} / \mathrm{L}$, micrograms per liter]

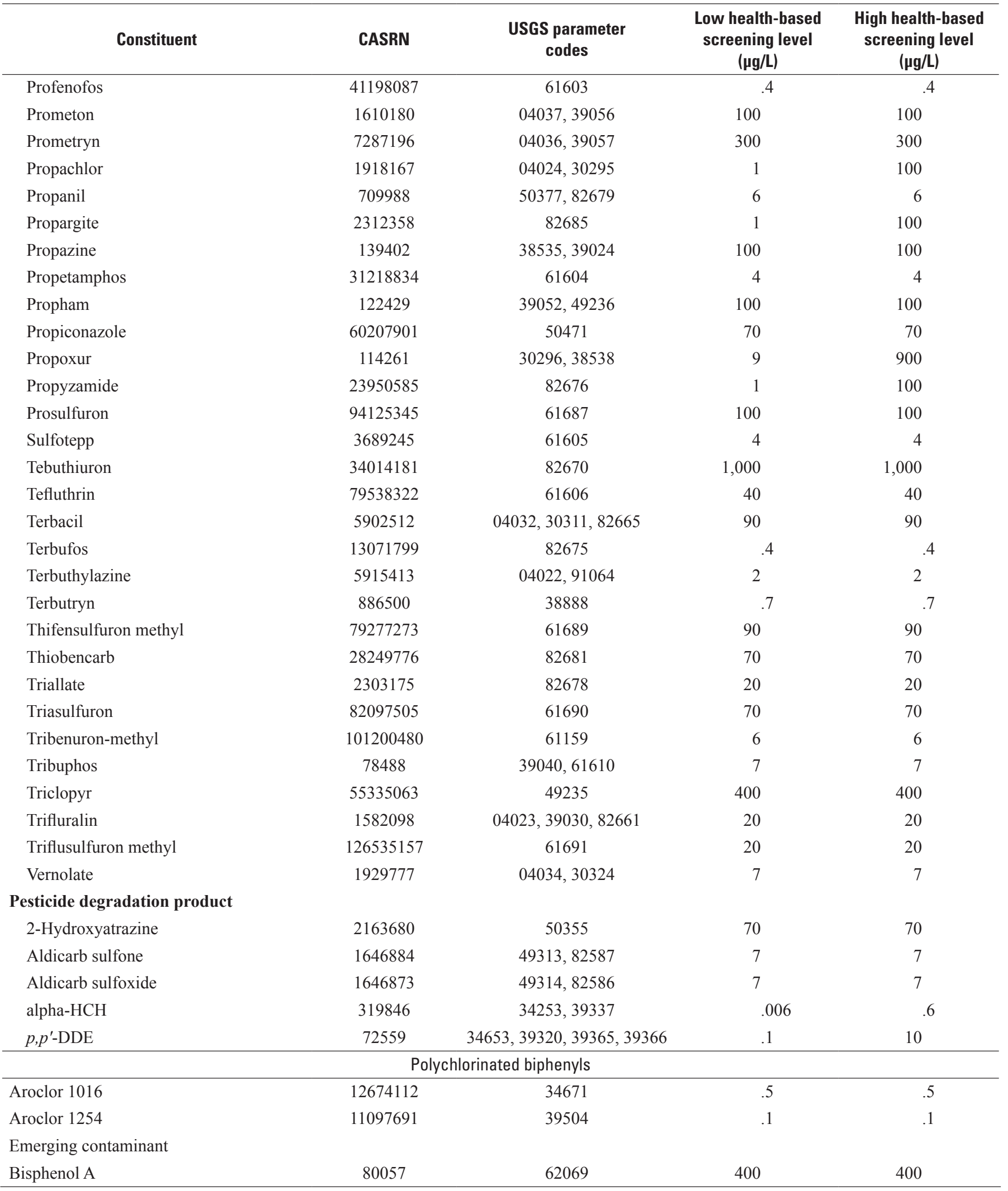


Table 8. Human-health screening levels for tapwater developed by the U.S. Environmental Protection Agency.

[Screening levels from U.S. Environmental Protection Agency, 2007c. CASRN, Chemcial Abstracts Service registry number; $\mu \mathrm{g} / \mathrm{L}$, micrograms per liter; $\mathrm{n} / \mathrm{a}$, not available; $<$, less than]

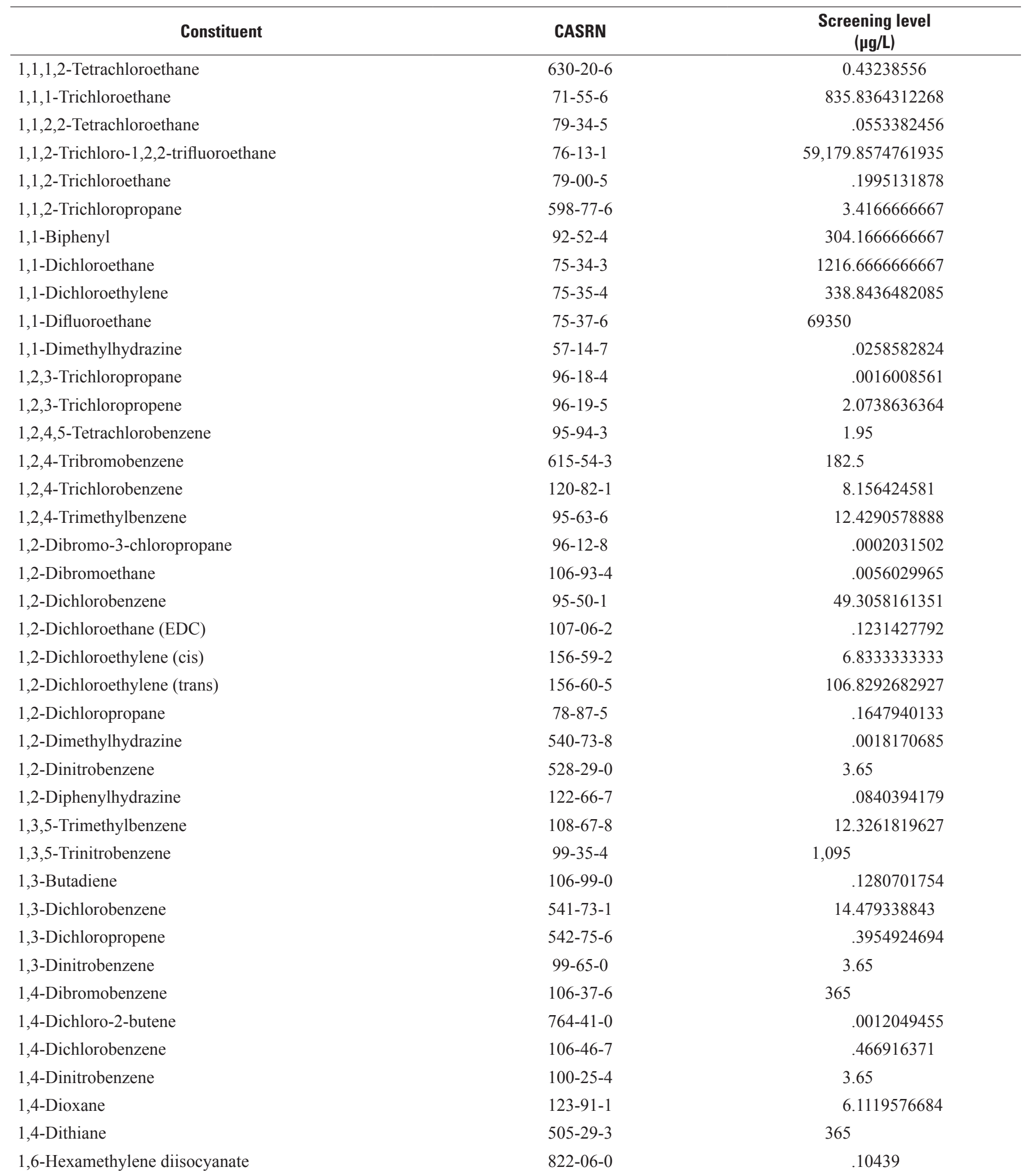


Table 8. Human-health screening levels for tapwater developed by the U.S. Environmental Protection Agency-Continued

[Screening levels from U.S. Environmental Protection Agency, 2007c. CASRN, Chemcial Abstracts Service registry number; $\mu \mathrm{g} / \mathrm{L}$, micrograms per liter; $\mathrm{n} / \mathrm{a}$, not available; $<$, less than]

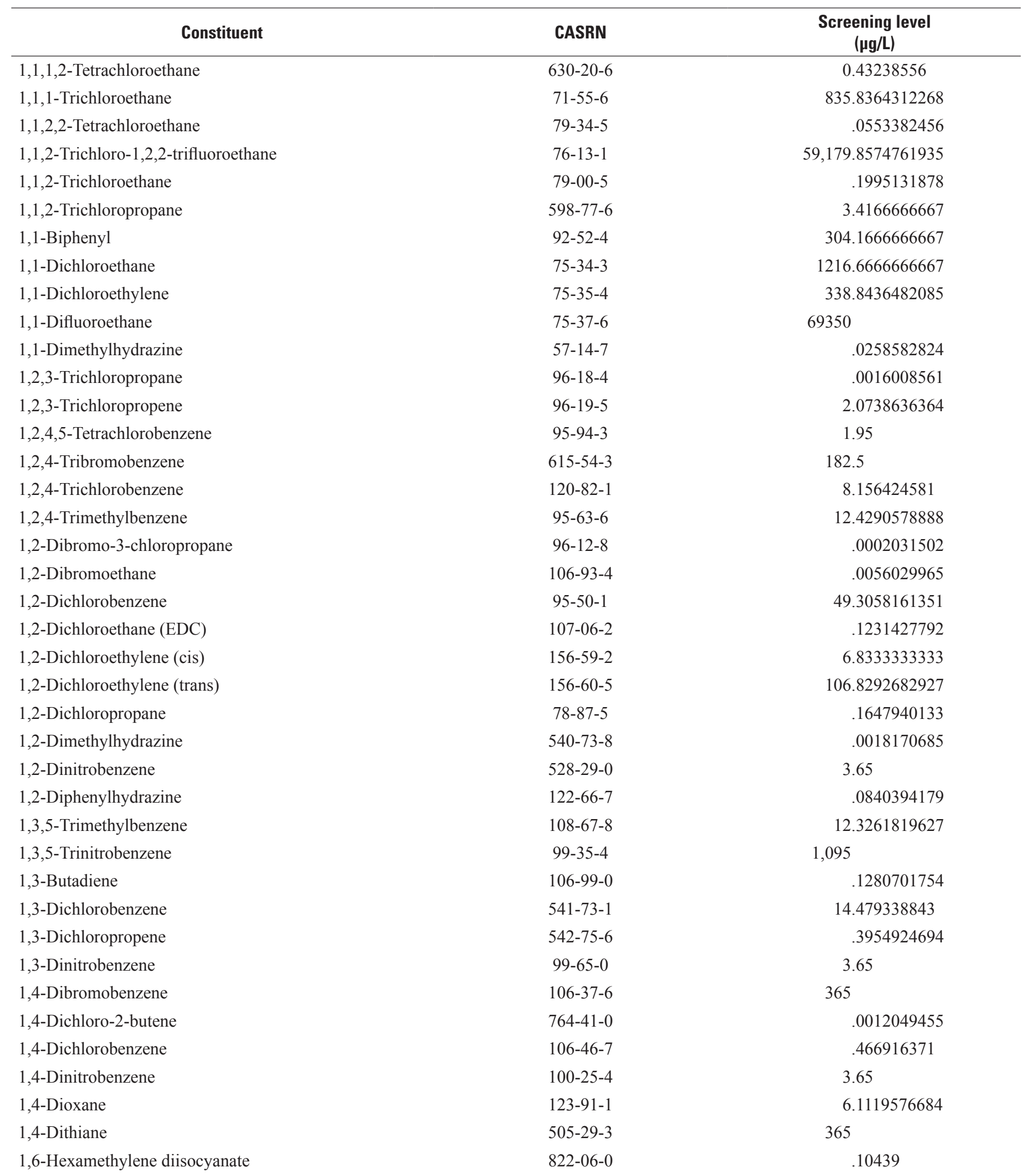




\section{Selected Investigations and Statistical Summary of Surface-Water Quality, North-Central New Mexico, 1985-2007}

Table 8. Human-health screening levels for tapwater developed by the U.S. Environmental Protection Agency-—Continued

[Screening levels from U.S. Environmental Protection Agency, 2007c. CASRN, Chemcial Abstracts Service registry number; $\mu \mathrm{g} / \mathrm{L}$, micrograms per liter; $\mathrm{n} / \mathrm{a}$, not available; $<$, less than]

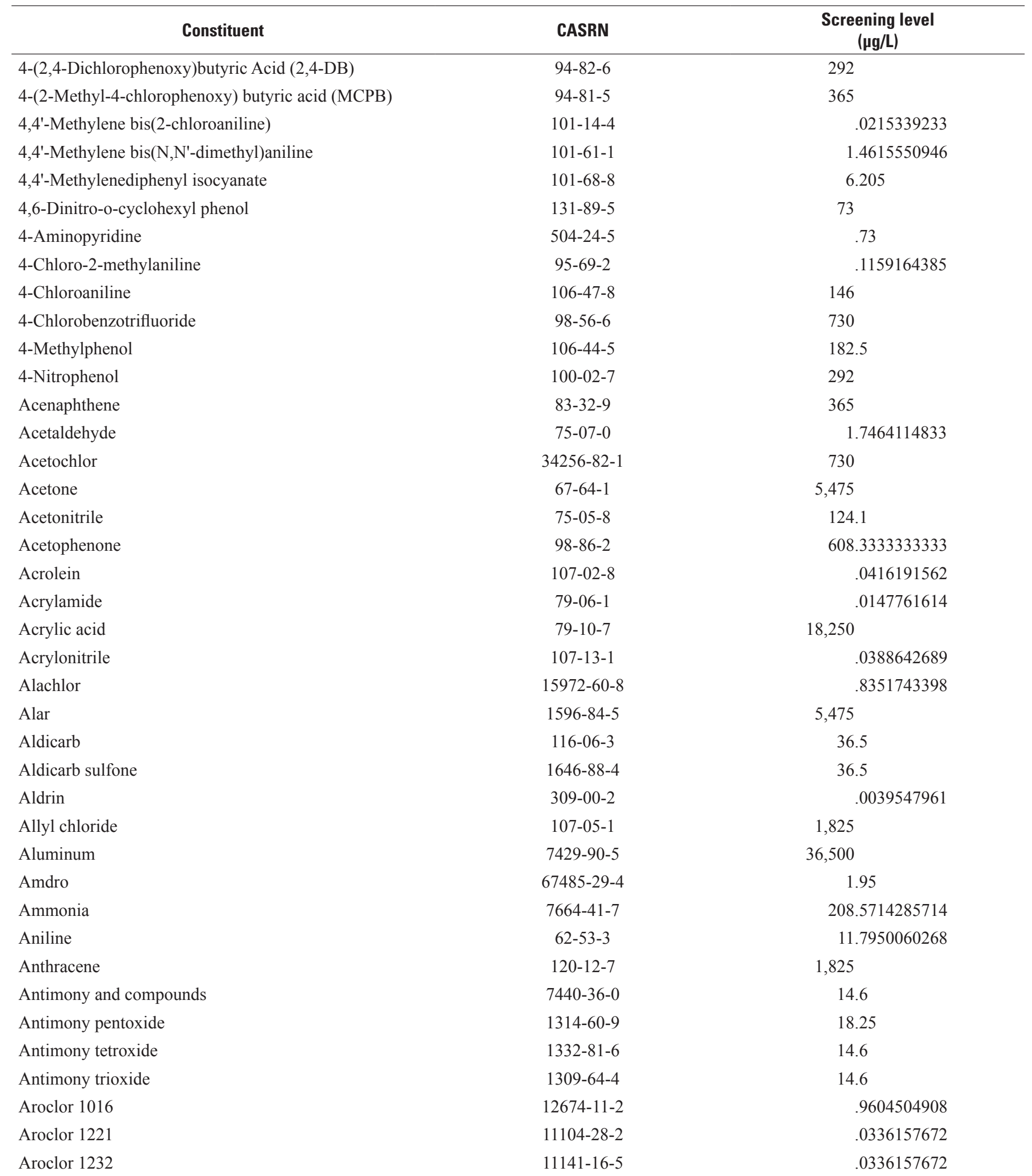


Table 8. Human-health screening levels for tapwater developed by the U.S. Environmental Protection Agency-Continued

[Screening levels from U.S. Environmental Protection Agency, 2007c. CASRN, Chemcial Abstracts Service registry number; $\mu \mathrm{g} / \mathrm{L}$, micrograms per liter; $\mathrm{n} / \mathrm{a}$, not available; $<$, less than]

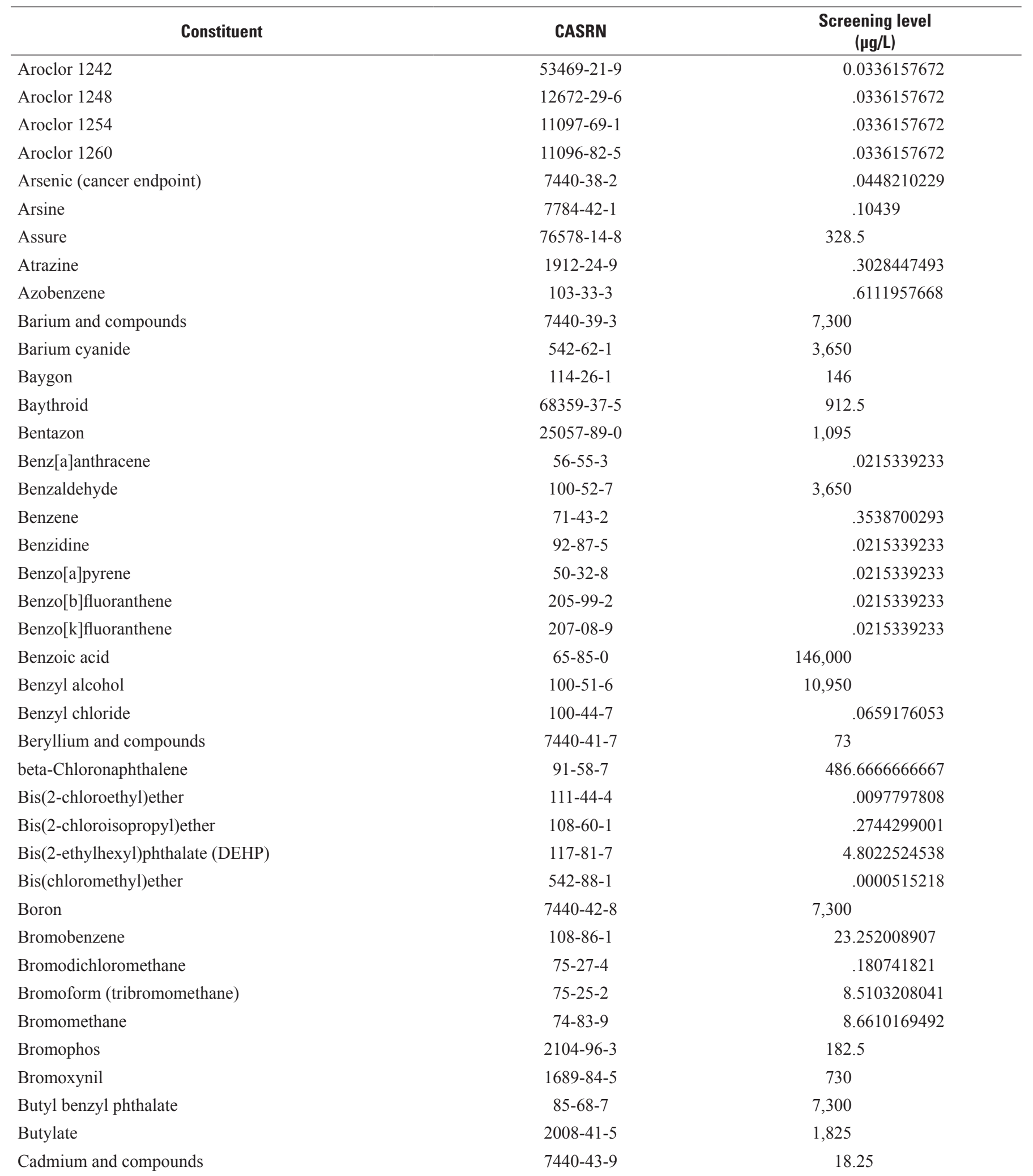


Table 8. Human-health screening levels for tapwater developed by the U.S. Environmental Protection Agency.-Continued

[Screening levels from U.S. Environmental Protection Agency, 2007c. CASRN, Chemcial Abstracts Service registry number; $\mu \mathrm{g} / \mathrm{L}$, micrograms per liter; $\mathrm{n} / \mathrm{a}$, not available; $<$, less than]

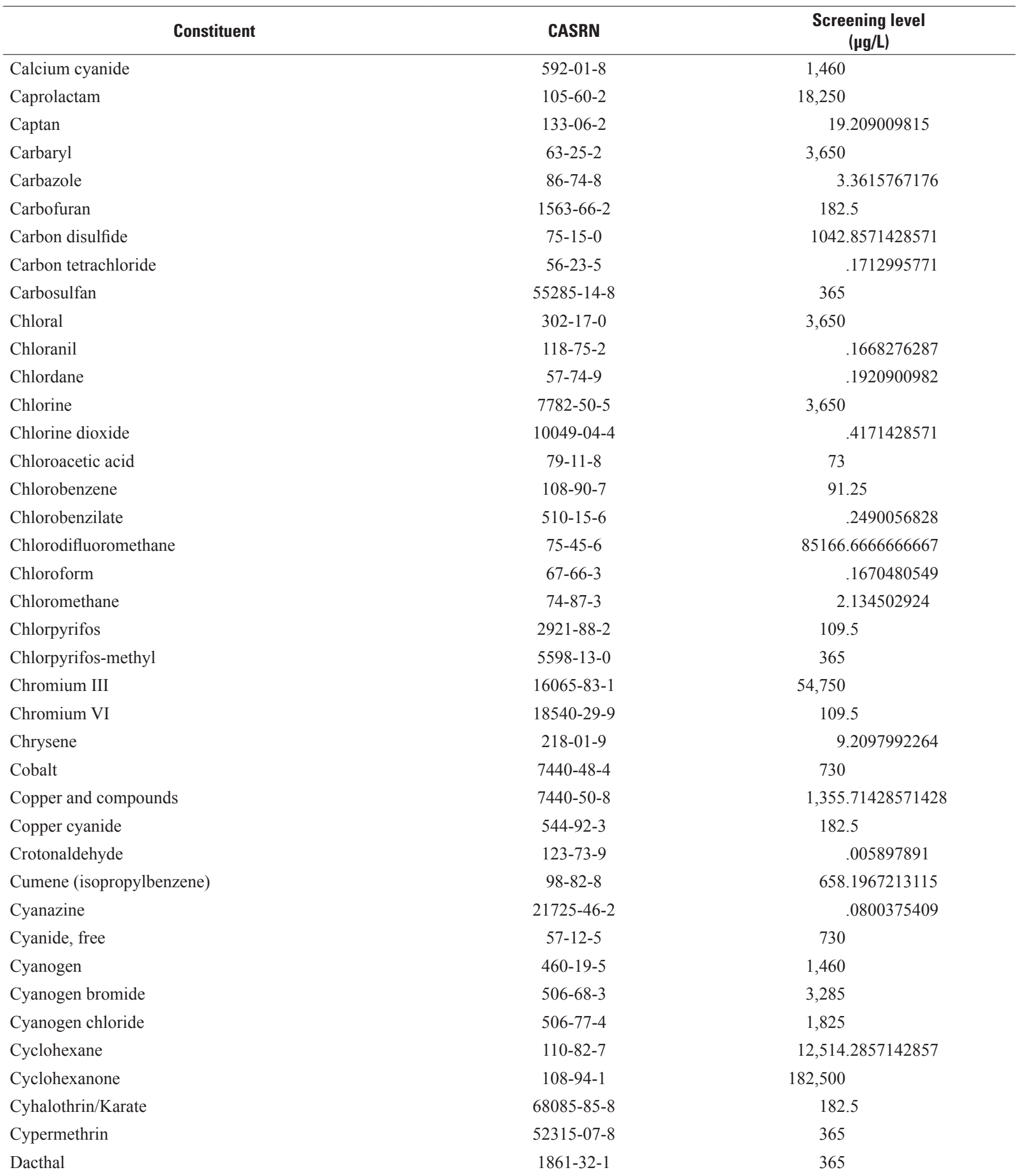


Table 8. Human-health screening levels for tapwater developed by the U.S. Environmental Protection Agency-Continued

[Screening levels from U.S. Environmental Protection Agency, 2007c. CASRN, Chemcial Abstracts Service registry number; $\mu \mathrm{g} / \mathrm{L}$, micrograms per liter; $\mathrm{n} / \mathrm{a}$, not available; $<$, less than]

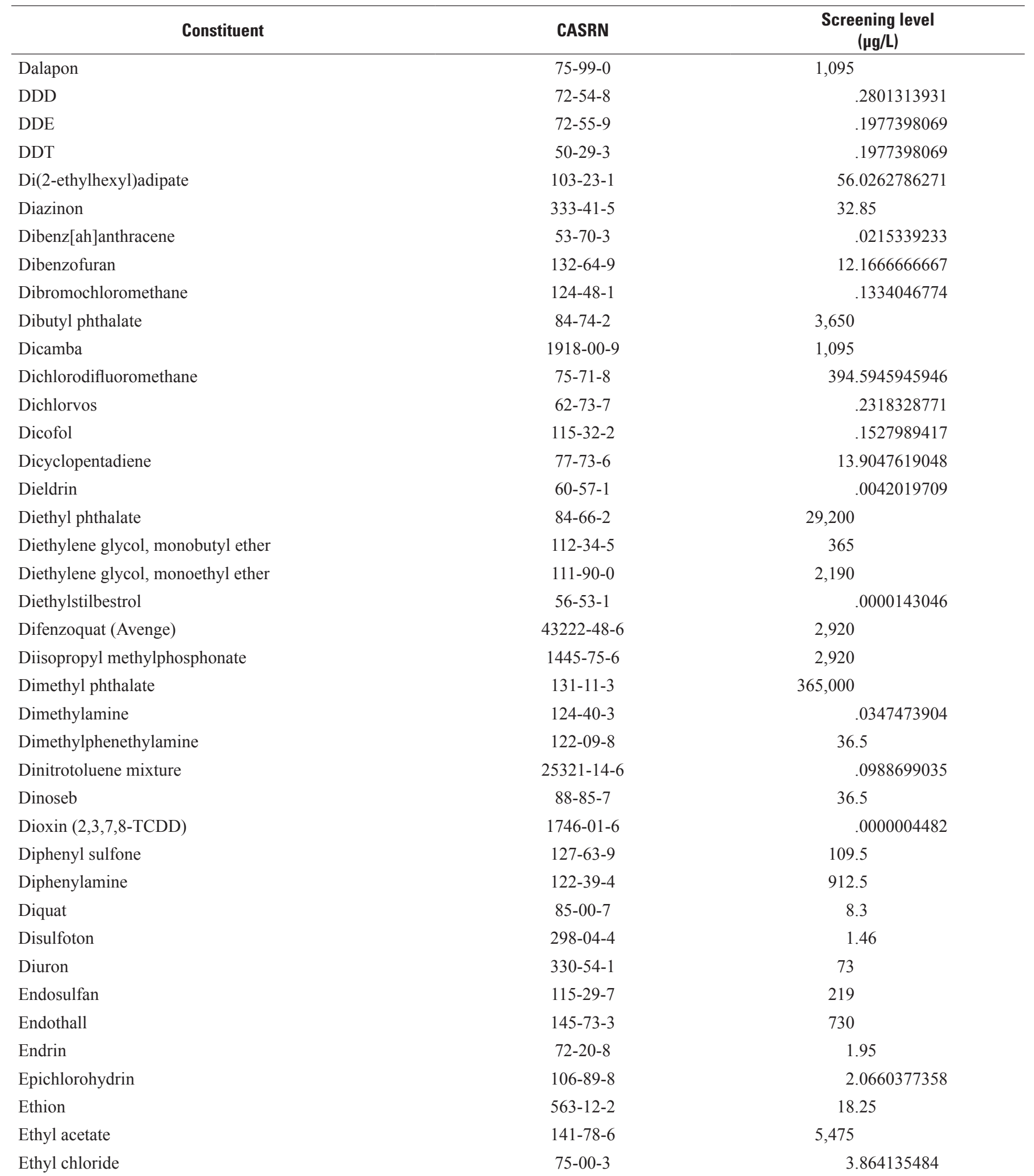


Table 8. Human-health screening levels for tapwater developed by the U.S. Environmental Protection Agency.-Continued

[Screening levels from U.S. Environmental Protection Agency, 2007c. CASRN, Chemcial Abstracts Service registry number; $\mu \mathrm{g} / \mathrm{L}$, micrograms per liter; $\mathrm{n} / \mathrm{a}$, not available; $<$, less than]

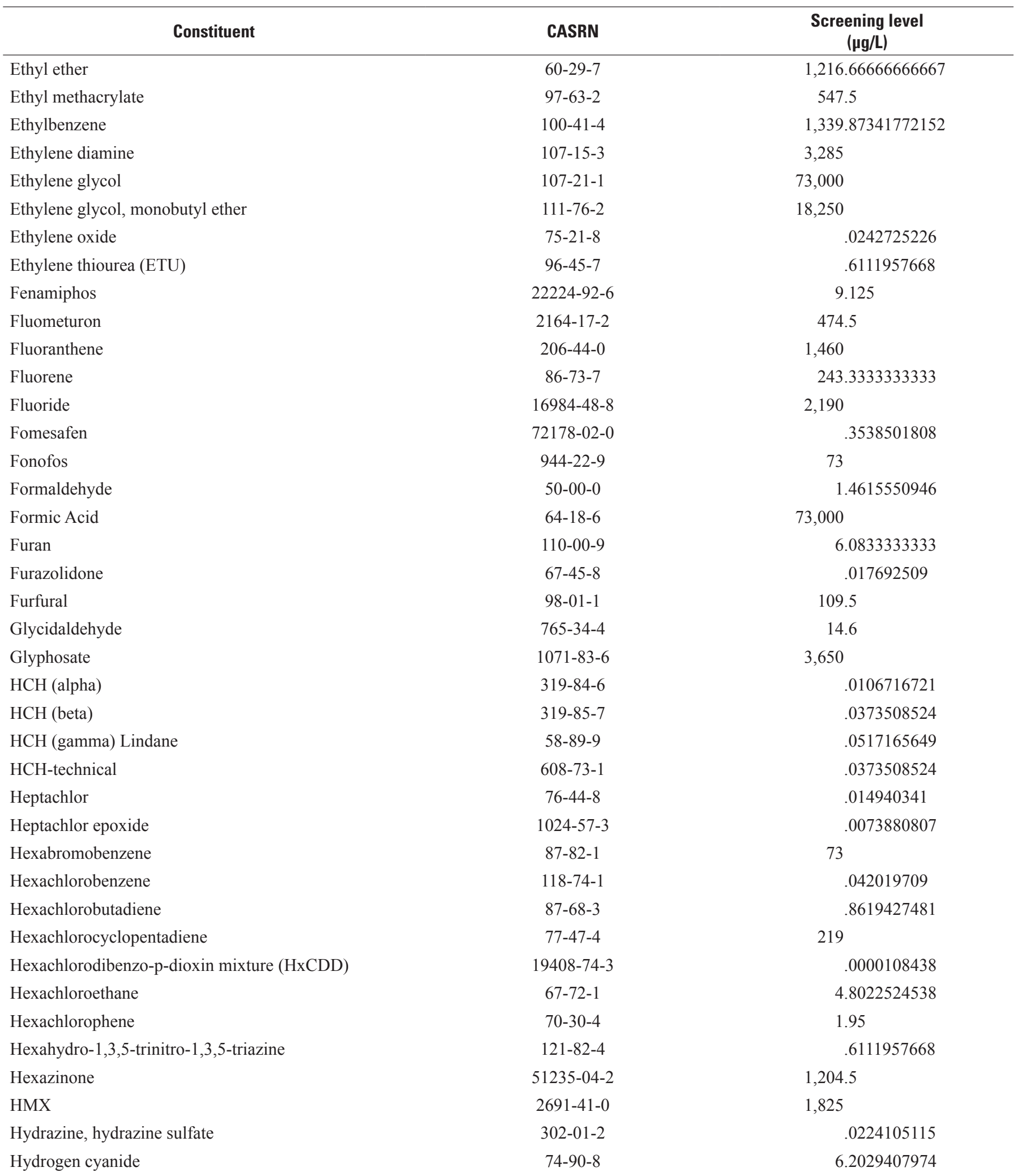


Table 8. Human-health screening levels for tapwater developed by the U.S. Environmental Protection Agency-Continued

[Screening levels from U.S. Environmental Protection Agency, 2007c. CASRN, Chemcial Abstracts Service registry number; $\mu \mathrm{g} / \mathrm{L}$, micrograms per liter; $\mathrm{n} / \mathrm{a}$, not available; $<$, less than]

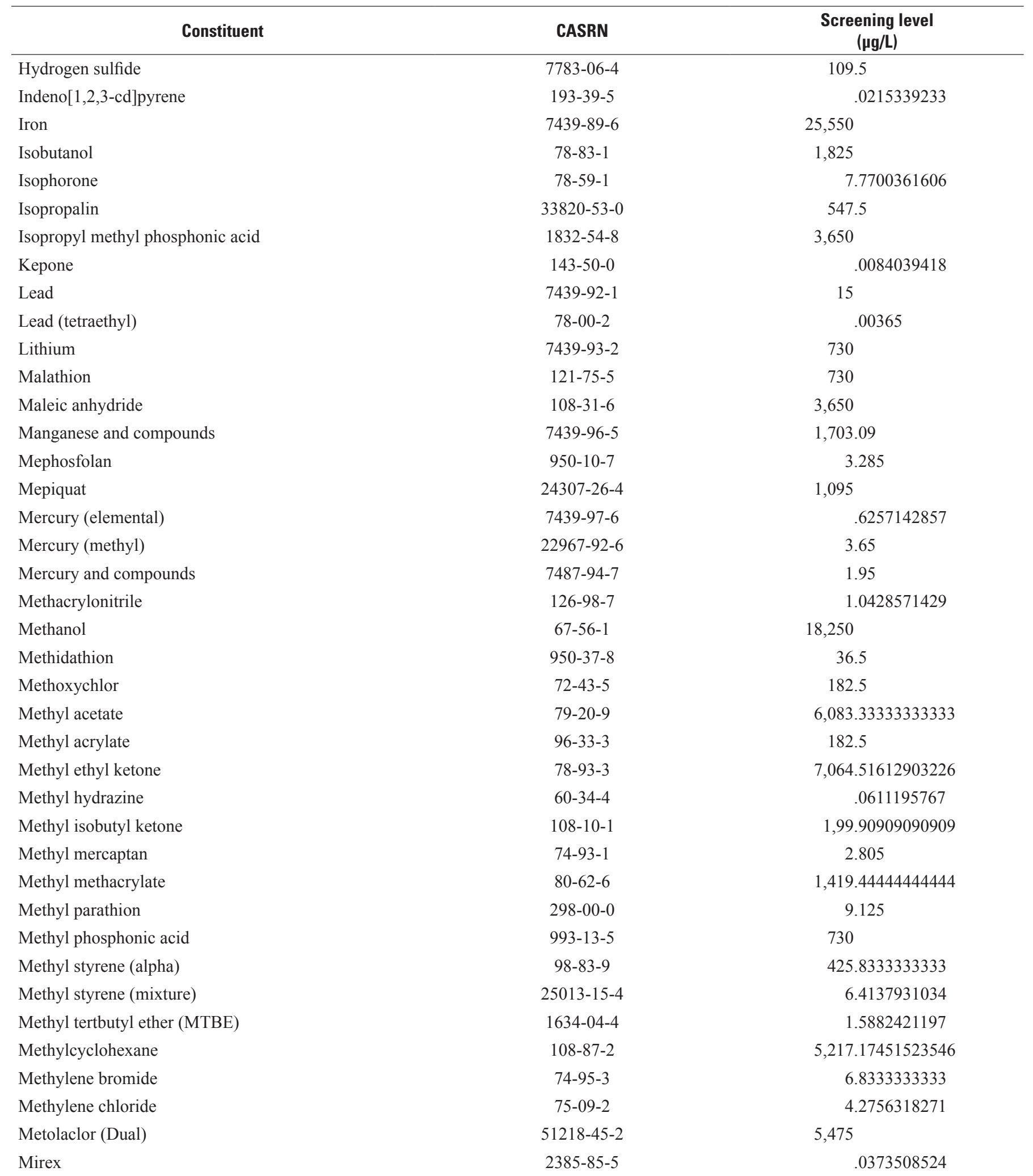


Table 8. Human-health screening levels for tapwater developed by the U.S. Environmental Protection Agency.-Continued

[Screening levels from U.S. Environmental Protection Agency, 2007c. CASRN, Chemcial Abstracts Service registry number; $\mu \mathrm{g} / \mathrm{L}$, micrograms per liter; $\mathrm{n} / \mathrm{a}$, not available; $<$, less than]

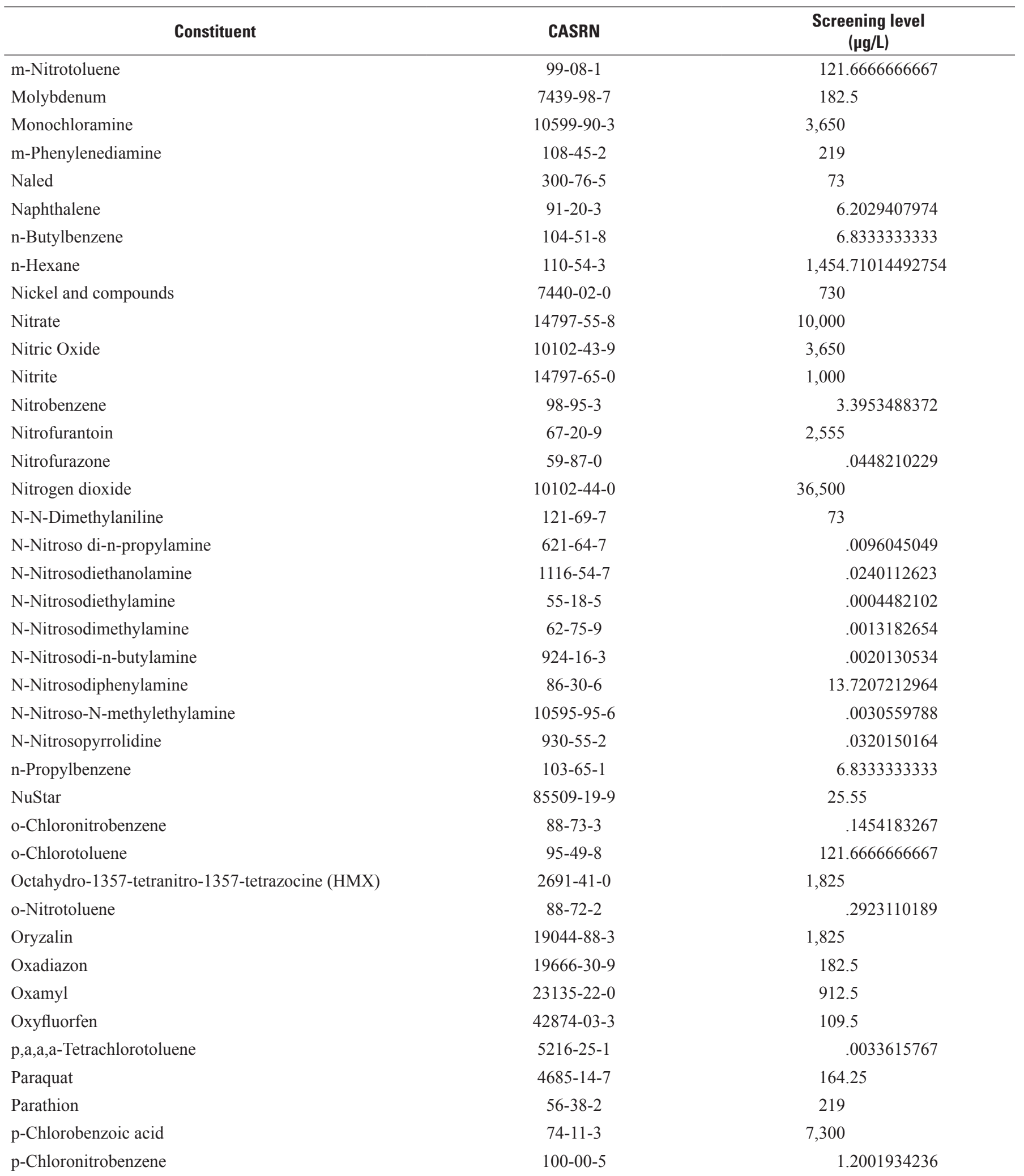


Table 8. Human-health screening levels for tapwater developed by the U.S. Environmental Protection Agency-—Continued

[Screening levels from U.S. Environmental Protection Agency, 2007c. CASRN, Chemcial Abstracts Service registry number; $\mu \mathrm{g} / \mathrm{L}$, micrograms per liter; $\mathrm{n} / \mathrm{a}$, not available; $<$, less than]

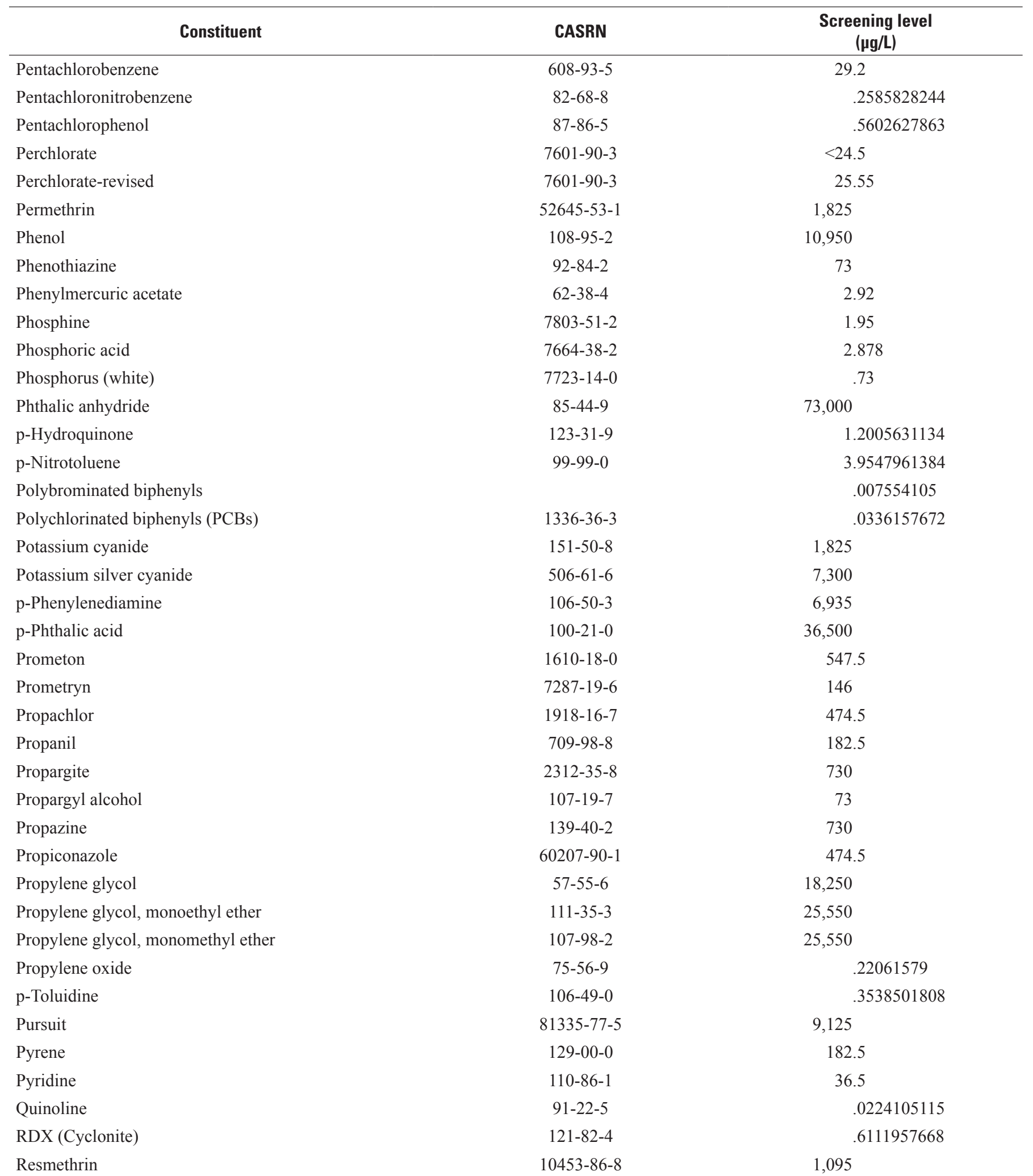


Table 8. Human-health screening levels for tapwater developed by the U.S. Environmental Protection Agency-—Continued

[Screening levels from U.S. Environmental Protection Agency, 2007c. CASRN, Chemcial Abstracts Service registry number; $\mu \mathrm{g} / \mathrm{L}$, micrograms per liter; $\mathrm{n} / \mathrm{a}$, not available; $<$, less than]

\begin{tabular}{|c|c|c|}
\hline Constituent & CASRN & $\begin{array}{c}\text { Screening level } \\
(\mu \mathrm{g} / \mathrm{L})\end{array}$ \\
\hline Ronnel & $299-84-3$ & 1,825 \\
\hline sec-Butylbenzene & $135-98-8$ & 6.8333333333 \\
\hline Selenious Acid & $7783-00-8$ & 182.5 \\
\hline Silver cyanide & $506-64-9$ & 3,650 \\
\hline Simazine & $122-34-9$ & .5602627863 \\
\hline Sodium azide & $26628-22-8$ & 146 \\
\hline Sodium cyanide & $143-33-9$ & 1,460 \\
\hline Strontium, stable & $7440-24-6$ & 21,900 \\
\hline Strychnine & $57-24-9$ & 1.95 \\
\hline Styrene & $100-42-5$ & $1,641.08527131783$ \\
\hline tert-Butylbenzene & $98-06-6$ & 6.8333333333 \\
\hline Tetrachloroethylene (PCE) & $127-18-4$ & .1045198387 \\
\hline Tetrachlorovinphos & $961-11-5$ & 2.8013139314 \\
\hline Tetrahydrofuran & $109-99-9$ & 8.8462545201 \\
\hline Thallic oxide & $1314-32-5$ & 2.555 \\
\hline Thallium & & 2.555 \\
\hline Thiobencarb & $28249-77-6$ & 365 \\
\hline Thiocyanate & $\mathrm{n} / \mathrm{a}$ & 7.3 \\
\hline Tin and compounds & $\mathrm{n} / \mathrm{a}$ & 21,900 \\
\hline Toluene & $108-88-3$ & 2281.2495009762 \\
\hline Toluene-2,4-diamine & $95-80-7$ & .0210098545 \\
\hline Toluene-2,5-diamine & $95-70-5$ & 21,900 \\
\hline Toluene-2,6-diamine & $823-40-5$ & 1,095 \\
\hline Toxaphene & $8001-35-2$ & .0611195767 \\
\hline Tributyltin oxide (TBTO) & $56-35-9$ & 1.95 \\
\hline Trichloroethylene (TCE) & $79-01-6$ & .0280149823 \\
\hline Trichlorofluoromethane & $75-69-4$ & $1,288.23529411765$ \\
\hline Triethylamine & $121-44-8$ & 12.1666666667 \\
\hline
\end{tabular}


Table 8. Human-health screening levels for tapwater developed by the U.S. Environmental Protection Agency-Continued

[Screening levels from U.S. Environmental Protection Agency, 2007c. CASRN, Chemcial Abstracts Service registry number; $\mu \mathrm{g} / \mathrm{L}$, micrograms per liter; $\mathrm{n} / \mathrm{a}$, not available; $<$, less than]

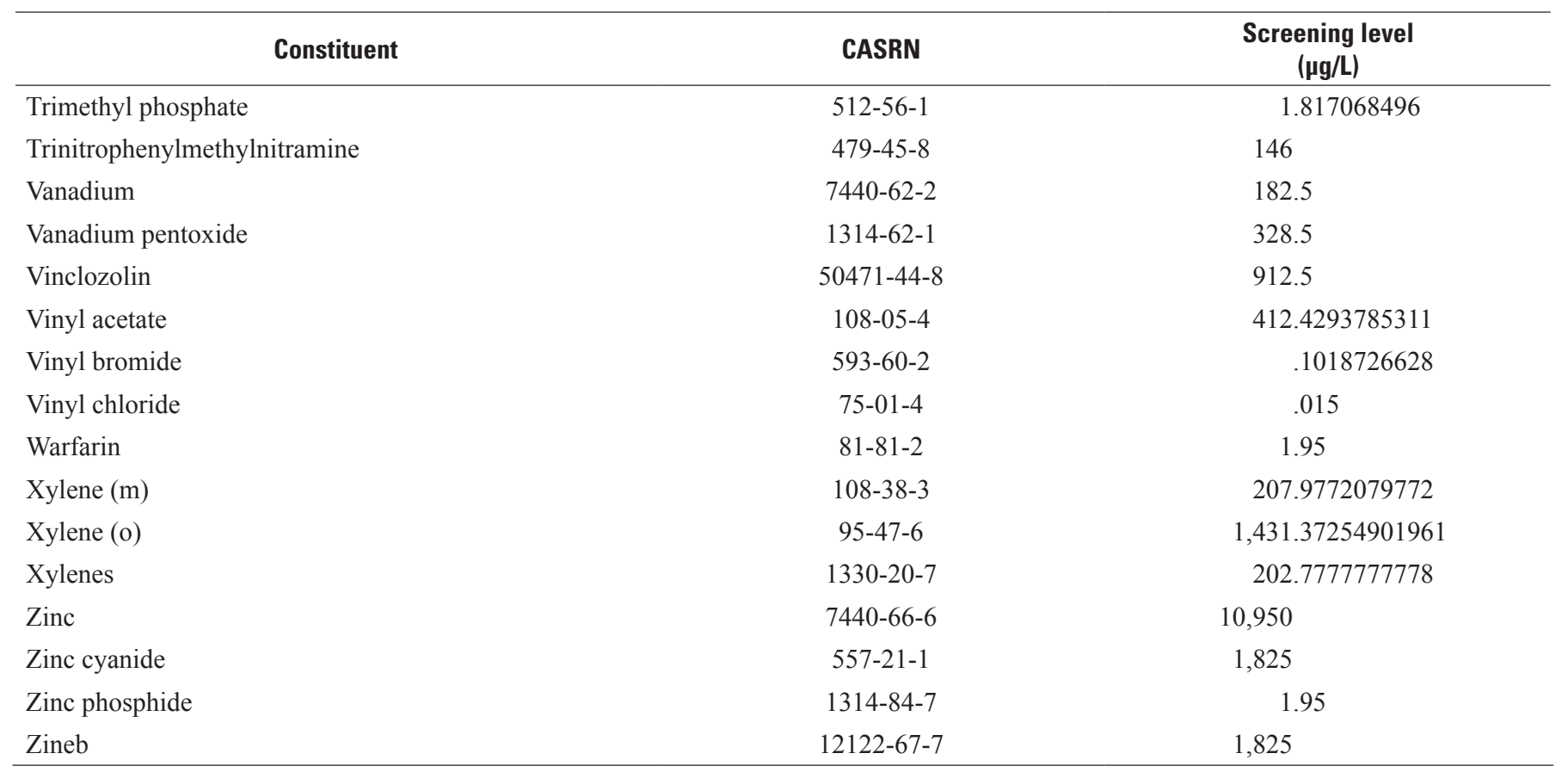


Table 9. Derived concentration guide reference values for ingested water for operational U.S. Department of Energy facilities.

[Values from U.S. Department of Energy, 2007. DCG, derived concentration guide; $\mu \mathrm{Ci} / \mathrm{mL}$, microcuries per milliliter; $\mathrm{pCi} / \mathrm{L}$, picocuries per liter]

\begin{tabular}{|c|c|c|}
\hline Radionuclide & $\begin{array}{c}\text { DCG } \\
\text { (ingested water) } \\
(\mu \mathrm{Ci} / \mathrm{mL})\end{array}$ & $\begin{array}{c}\text { DCG } \\
\text { (ingested water) } \\
\text { (pCi/L) }\end{array}$ \\
\hline Americium-241 & 0.00000003 & 30 \\
\hline Cesium-137 & .000003 & 3,000 \\
\hline Strontium-90 & .000001 & $1,000-10,000$ \\
\hline Plutonium-238 & .00000004 & $40-3,000$ \\
\hline Plutonium-239 & .00000003 & $30-2,000$ \\
\hline Plutonium-240 & .00000003 & $30-2,000$ \\
\hline Radium-224 & .0000004 & 400 \\
\hline Radium-226 & .0000001 & 100 \\
\hline Radium-228 & .0000001 & 100 \\
\hline Thorium-228 & .0000004 & 400 \\
\hline Thorium-230 & .0000003 & 300 \\
\hline Thorium-232 & .00000005 & 50 \\
\hline Tritium & .002 & $2,000,000$ \\
\hline Uranium-234 & .0000005 & $500-5,000$ \\
\hline Uranium-235 & .0000006 & $600-5,000$ \\
\hline Uranium-236 & .0000005 & $500-6,000$ \\
\hline Uranium-238 & .0000006 & $600-6,000$ \\
\hline Uranium-Natural & .0000006 & $600-6,000$ \\
\hline
\end{tabular}

\section{References Cited}

Abeyta, C.G., and Lusk, J.D., 2004, Hydrologic and biologic data for the water-quality assessment in relation to Rio Grande silvery minnow habitats, Middle Rio Grande, New Mexico, 2002-2003: Draft report to U.S. Fish and Wildlife Service, New Mexico Ecological Services Field Office, Albuquerque, N. Mex.

Albuquerque Bernalillo County Water Utility Authority (ABCWUA), 2011 project overview - two years in, drinking water project delivers on promises: accessed July 6, 2011, at http://www.abcwua.org/content/view/527/819/.

Anderholm, S.K., Radell, M.J., and Richey, S.F., 1995, Waterquality assessment of the Rio Grande Valley study unit, Colorado, New Mexico, and Texas - analysis of selected nutrient, suspended-sediment, and pesticide data: U.S. Geological Survey Water-Resources Investigations Report 94-4061, 203 p.

Bartolino, J.R., and Cole, J.C., eds., 2002, Ground-water resources of the Middle Rio Grande Basin, New Mexico: U.S. Geological Survey Circular 1222, 132 p.

Bexfield, L.M., and Anderholm, S.K., 2002, Estimated waterlevel declines in the Santa Fe Group aquifer system in the Albuquerque area, central New Mexico, predevelopment to 2002: U.S. Geological Survey Water-Resources Investigations Report 02-4223, 1 sheet.

Carter, L.F., 1997, Water-quality assessment of the Rio Grande Valley, Colorado, New Mexico, and Texas; fish communities at selected sites, 1993-95: U.S. Geological Survey Water- Resources Investigations Report 97-4017, 27 p.

City of Albuquerque, 1997, Water resources management strategy, Public Works Department: accessed July 6, 2011, at http://www.abcwua.org/content/view/190/332/.

Gallaher, B.M., and Koch, R.J., 2004, Cerro Grande fire impacts to water quality and steam flow near Los Alamos National Laboratory — results of four years of monitoring: Los Alamos National Laboratory report LA-14177, 195 p.

Gonzales, G.J., and Montoya, J.T., 2005, Polychlorinated biphenyls (PCBs) in the Rio Grande sampled using semipermeable membrane devices ("fat bags"): Los Alamos National Laboratory report LA-14200, 18 p.

Healy, D.F., 1997, Water-quality assessment of the Rio Grande Valley, Colorado, New Mexico, Texas-summary and analysis of water-quality data for the basic-fixedsite network, 1993-95: U.S. Geological Survey Water Resources Investigations Report 97-4212, 82 p. 
Helsel, D.R., 2005, Nondetects and data analysis — statistics for censored environmental data: New York, John Wiley and Sons, $250 \mathrm{p}$.

Kelly, Todd, and Taylor, H.E., 1996, Concentrations and loads of selected trace elements and other constituents in the Rio Grande in the vicinity of Albuquerque, New Mexico, 1994: U.S. Geological Survey Open-File Report 96-0126, 45 p.

Langman, J.B., and Anderholm, S.K., 2004, Effects of reservoir installation, San Juan-Chama Project water, and reservoir operations on streamflow and water quality in the Rio Chama and Rio Grande, northern and central New Mexico, 1938-2000: U.S. Geological Survey Scientific Investigations Report 2004-5188, 47 p.

Langman, J.B., and Nolan, E.O., 2005, Streamflow and waterquality trends of the Rio Chama and Rio Grande, northern and central New Mexico, water years 1985 to 2002: U.S. Geological Survey Scientific Investigations Report 2005-5118, 36 p.

Los Alamos National Laboratory, 2005, Los Alamos National Laboratory environmental surveillance at Los Alamos during 2005: Los Alamos National Laboratory report LA-14304-ENV, 286 p.

McQuillan, Dennis, Hopkins, Scott, Chapman, T.H., Sherrell, Ken, and Mills, David, 2002, Drug residues in ambient water-initial surveillance in New Mexico, USA: accessed July 10, 2007, at http://www.nmenv.state.nm.us/fod/ LiquidWaste/pharm\%20paper.pdf.

Miller, L.K., Moquino, R.L., and Hill, B.A., 1997, Waterquality assessment of the Rio Grande Valley, Colorado, New Mexico, and Texas - water-quality data for watercolumn, suspended-sediment, and bed-material samples collected at selected surface-water sites in the upper Rio Grande Basin, June and September 1994: U.S. Geological Survey Open-File Report 97-644, 18 p.

Moore, S.J., and Anderholm, S.K., 2002, Spatial and temporal variations in streamflow, dissolved solids, nutrients, and suspended sediment in the Rio Grande Valley study unit, Colorado, New Mexico, and Texas, 1993-95: U.S. Geological Survey Water-Resources Investigations Report 02-4224, $52 \mathrm{p}$.

New Mexico Environment Department, 2006, Quality assurance project plan for water quality management programs: Santa Fe, Surface Water Quality Bureau, revision no. 1, sections no.1-3, app. A-C, variously paged.

Passell, H.D., Dahm, C.N., and Bedrick, E.J., 2004, Hydrological and geochemical trends and patterns in the upper Rio Grande, 1975 to 1999: Journal of the American Water Resources Association, v. 40, no. 1, p. 111-128.
Passell, H.D., Dahm, C.N., and Bedrick, E.J., 2005, Nutrient and organic carbon trends and patterns in the upper Rio Grande, 1975-1999: Science of the Total Environment, v. 345, no. 1-3, p. 239-260.

Plummer, L.N., Bexfield, L.M., Anderholm, S.K., Sanford, W.E., Busenburg, Eurybiades, 2004, Geochemical characterization of ground-water flow in the Santa Fe Group aquifer system, Middle Rio Grande Basin, New Mexico: U.S. Geological Survey Water-Resources Investigations Report 03-4131, 395 p.

Taylor, H.E., Antweiler, R.C., Roth, D.A., Brinton, T.I., Peart, D.B., and Healy, D.F., 2001, The occurrence and distribution of selected trace elements in the Upper Rio Grande and tributaries in Colorado and Northern New Mexico: Archives of Environmental Contamination and Toxicology, v. 41, p. 410-426.

Toccalino, Patricia, Nowell, Lisa, Wilber, William, Zogorski, John, Donohue, Joyce, Eiden, Catherine, Krietzman, Sandra, and Post, Gloria, 2003, Development of healthbased screening levels for use in State- or local-scale water-quality assessments: U.S. Geological Survey WaterResources Investigations Report 03-4054, 22 p.

Toccalino, P.L., 2007, Development and application of healthbased screening levels for use in water quality assessments: U.S. Geological Survey Scientific Investigations Report 2007-5106, 12 p.

U.S. Department of Energy, 2007, Radiation protection of the public and the environment: accessed July 6, 2011, at http:// www.doeal.gov/SWEIS/DOEDocuments/001\%20DOE\%20 54005.pdf.

U.S. Environmental Protection Agency, 2007a, Drinking water contaminants: accessed July 12, 2007, at http://www.epa. gov/safewater/contaminants/index.html\#primary.

U.S. Environmental Protection Agency, 2007b, Secondary drinking water regulations - guidance for nuisance chemicals: accessed December 28, 2007, at http://www.epa. gov/safewater/consumer/2ndstandards.html.

U.S. Environmental Protection Agency, 2007c, EPA Region 6 human health medium-specific screening levels: accessed July 12, 2007, at http://www.epa.gov/earth1r6/6pd/rcra_c/ pd-n/screen.htm.

U.S. Environmental Protection Agency, 2007d Region 6 multimedia programs - base closure team: accessed September 5, 2007, at http://www.epa.gov/earth1r6/6pd/ rcra_c/pd-n/. 
U.S. Environmental Protection Agency, 2011, Regulating public water systems and contaminants under the Safe Drinking Water Act: accessed July 6, 2011, at http:// water.epa.gov/lawsregs/rulesregs/regulatingcontaminants/ basicinformation.cfm.

U.S. Geological Survey, 2007, Health-based screening levels - a tool for evaluating what water-quality data may mean to human health: accessed July 12, 2007 , at http://infotrek.er.usgs.gov/traverse/f?p=HBSL:H OME:16423610965685574190.

U.S. Geological Survey, variously dated, National field manual for the collection of water-quality data: U.S. Geological Survey Techniques of Water-Resources Investigations, book 9, chaps. A1-A9. (Also available at http://water.usgs.gov/ owq/FieldManual/.)

U.S. Geological Survey, variously dated, Laboratory analysis: U.S. Geological Survey Techniques of Water-Resources Investigations, book 5, chaps. A1-A6. (Also available at http://pubs.usgs.gov/twri/.)
U.S. Nuclear Regulatory Commission, 2004, Multi-agency radiological laboratory analytical protocols manual, planning, assessment, implementation - part II, vol. III, chaps. 18-20, app. G: Washington, D.C., U.S. Nuclear Regulatory Commission, NUREG-1576, EPA 402-B-04001C, NTIS PB2004-105421, July 2004, variously paged.

Wilcox, L.V., 1968, Discharge and salt burden of the Rio Grande above Fort Quitman, Texas and salt-balance conditions on the Rio Grande Project - summary report for the 30 year period 1934-1963: U.S. Department of Agriculture, U.S. Salinity Laboratory.

Wilcox, R., 1997, Concentrations of selected trace elements and other constituents in the Rio Grande and in fish tissue in the vicinity of Albuquerque, New Mexico 1994 to 1996: U.S. Geological Survey Open-File Report 97-0667, 173 p.

Wilkins, D.W., 1986, Geohydrology of the southwest alluvial basins regional aquifer systems analysis, parts of Colorado, New Mexico, and Texas: U.S. Geological Survey WaterResources Investigations Report 84-4224, 61 p. 
